معوقات تطبيق أبعاد المنظمة المتعلمة بالمدارس الثانوية للبنات بمدينة تبوك

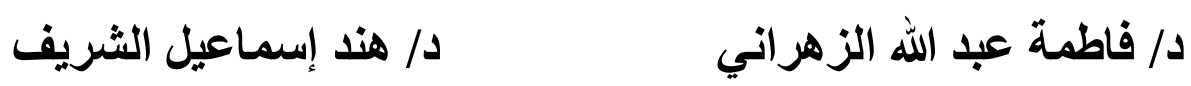

المملكة العربية السعودية

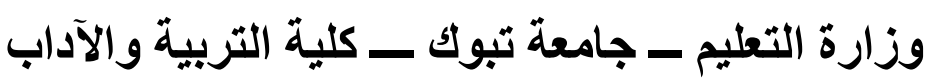

قسم الإدارة والتخطيط التريوي 


\section{مستخلص الدراسة:}

هدفت الدراسة إلى الكثف عن المعوقات التي تواجه الإدارة المدرسية عند تطبيق أبعاد

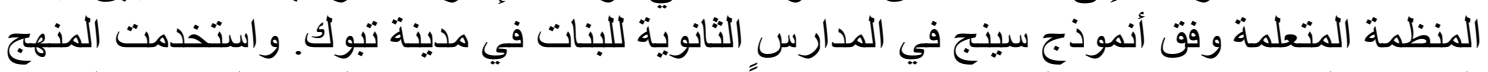

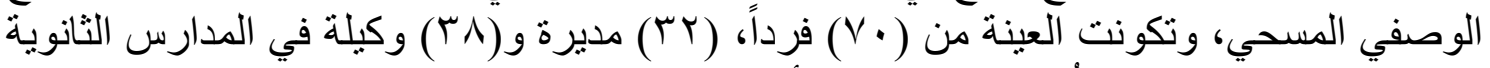

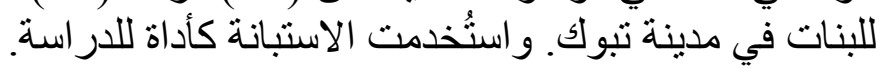

وخلصت الدراسة إلى مجموعة من النتائج، منها: أن المعوقات التي تواجه الإدارة

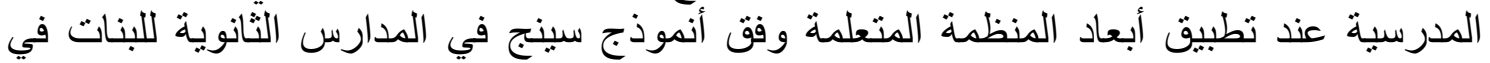

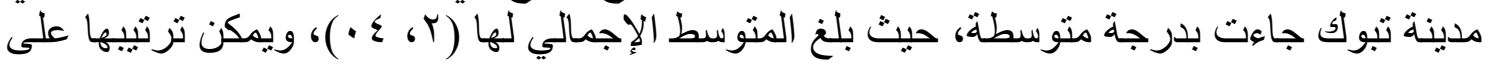

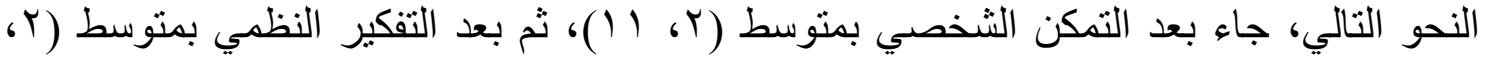

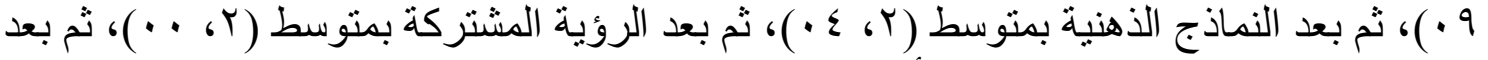

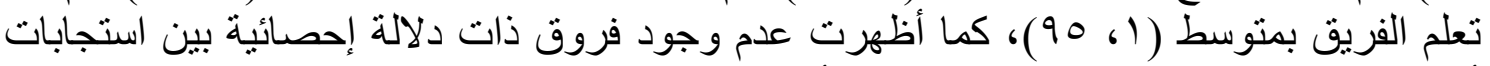

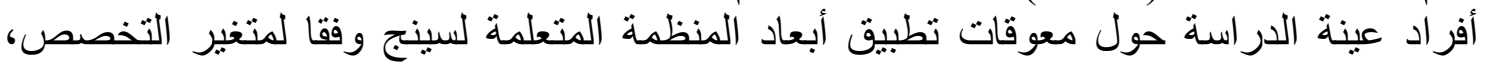

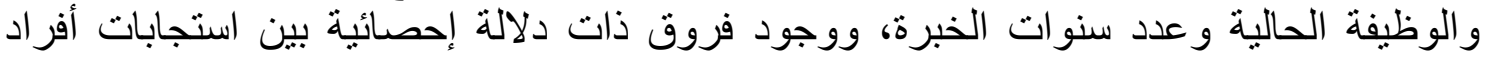

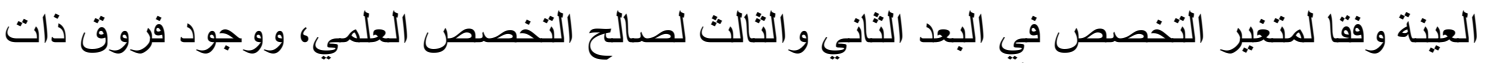

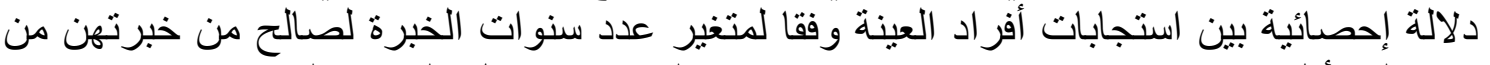

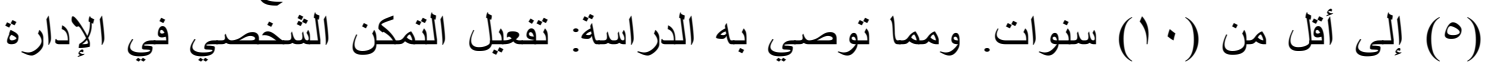

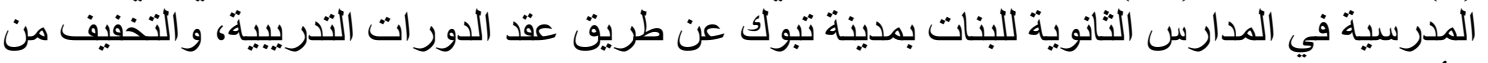

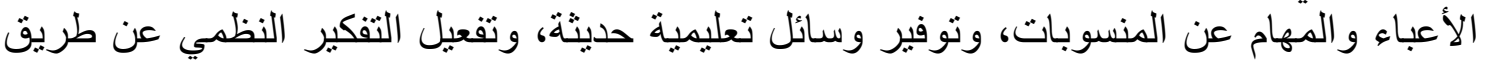

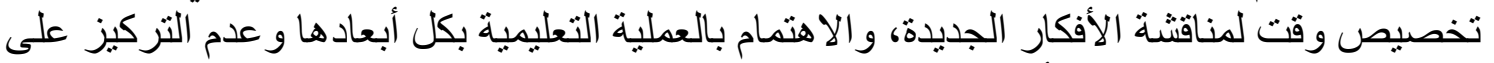

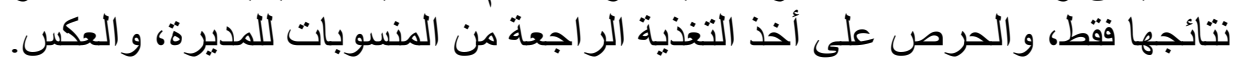


تأني مؤسسات التعليم بوجه عام في مقدمات اهتمامات المجتمع، للاور الذي تلعبه في تأهيل

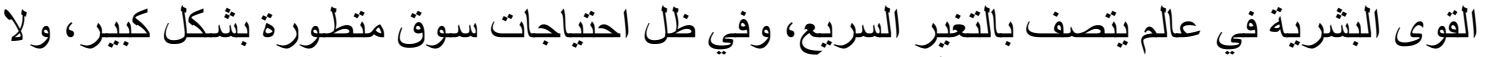

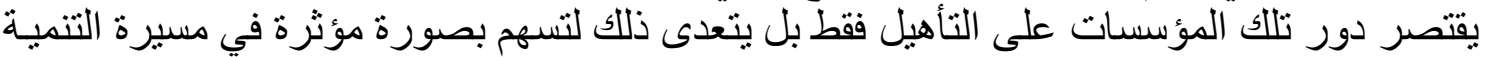

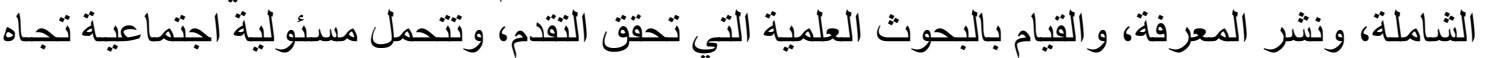

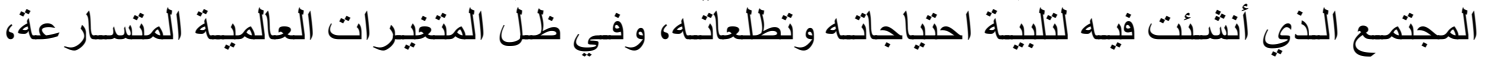

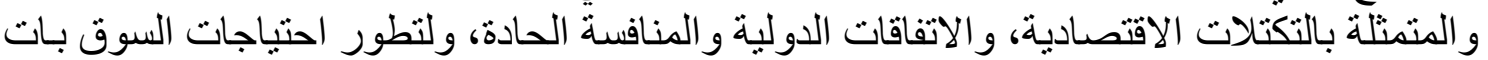

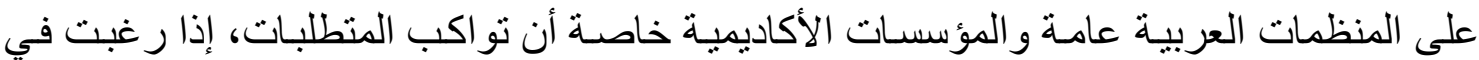

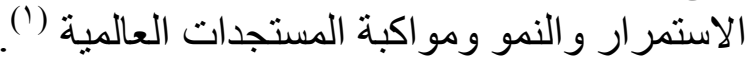

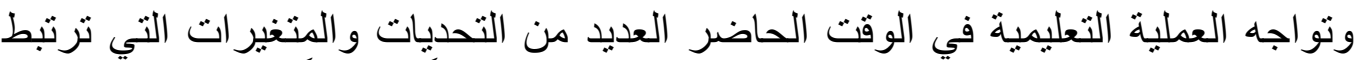

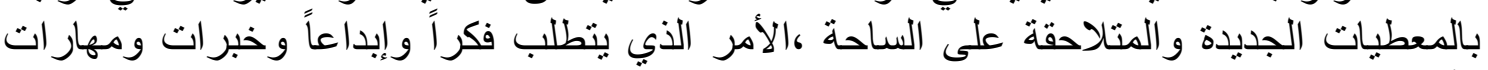

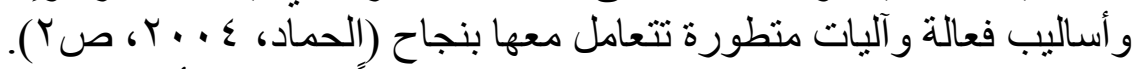

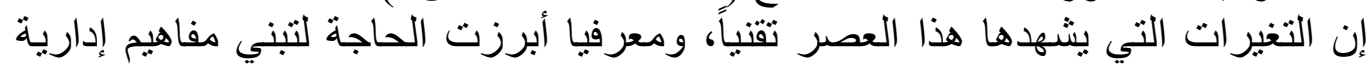

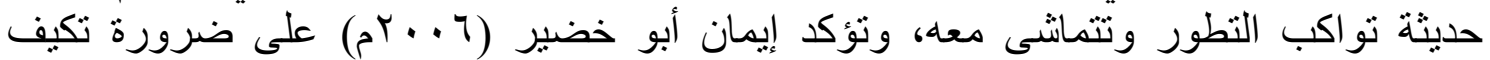

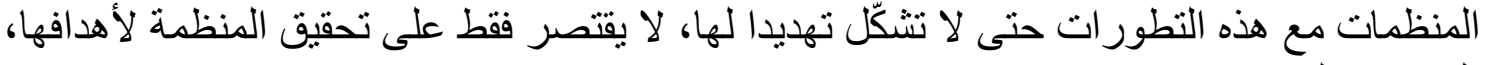
بل يتعداه إلى وجودهات مدها.

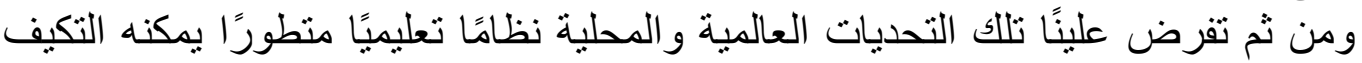

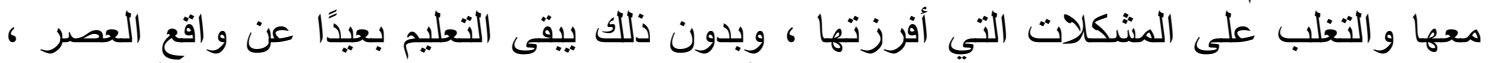

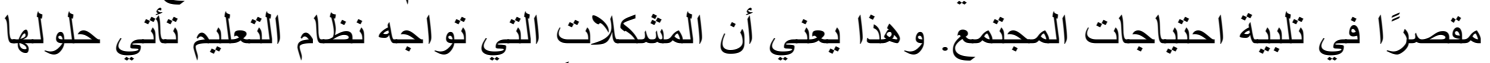

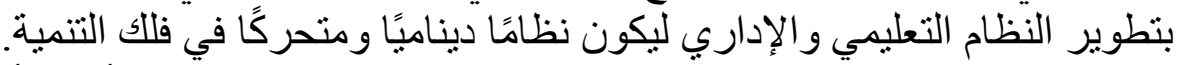

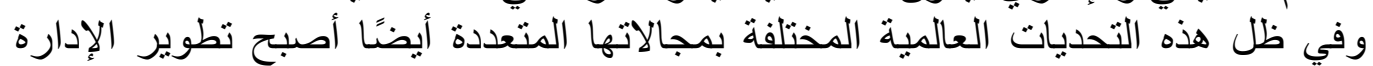

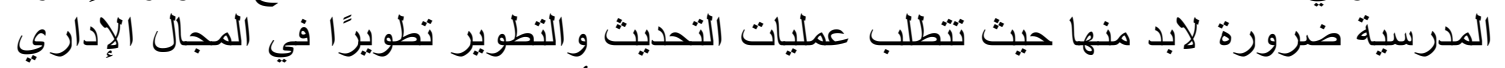

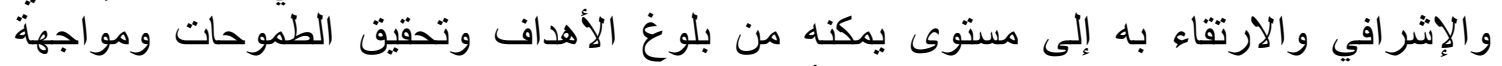

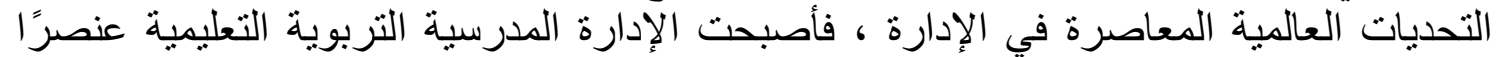

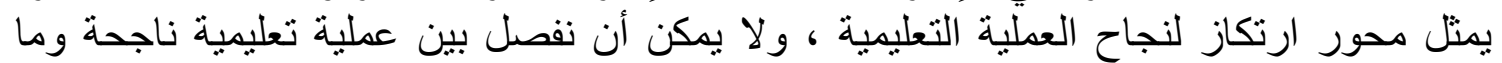

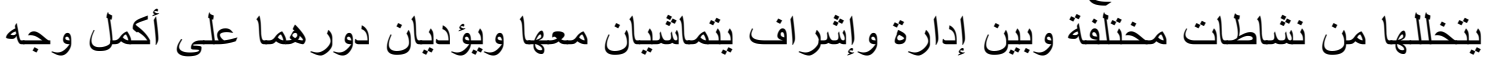

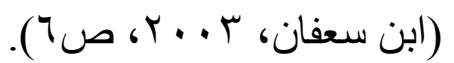

وبهذا المنظور يتطلب الأمر تطوير المدرسة بشكل كامل بكل عناصرها لأنها منظومة

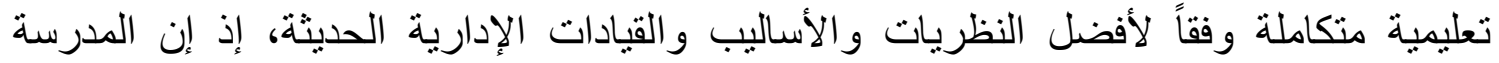

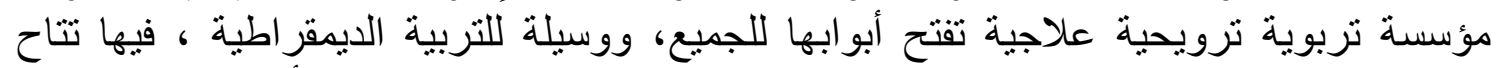

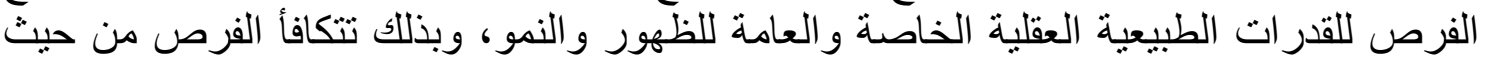

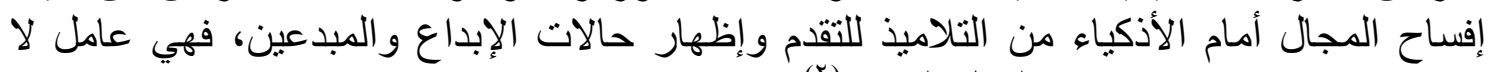

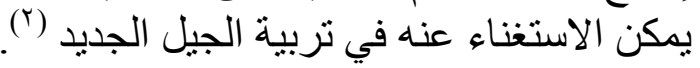

( ( المنظمة العربية للتنمية الإدارية: الملتقى العربى الثالث، المواصفات العالمية للجامعات، عدن، اليمن، ب. . ب، (1) طارق عبد الحميد البلري : الأساليب القيادية والإدارية في المؤسسات التعليمية، دار الفكر، الأردن، ا . . F م 
وبناء على ذللك فقد تغير دور المدرسة الحديثة حيث أصبح من مهامها تطوير ومواكبة

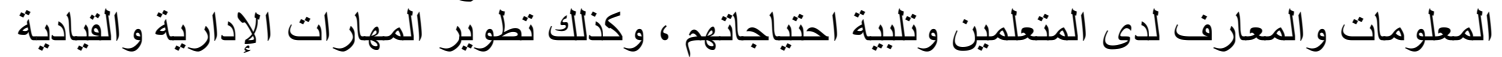

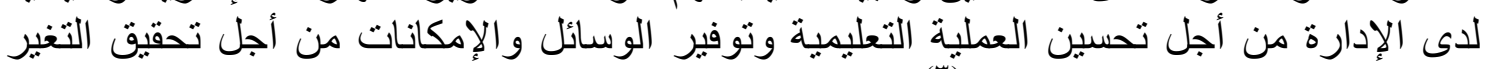

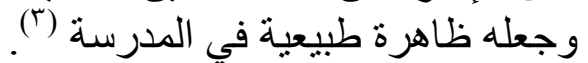
و على الرغم من ازدياد أهمية التعليم قبل الجامية الجيعي لدى جميع الدول العربية بعامة، ودول

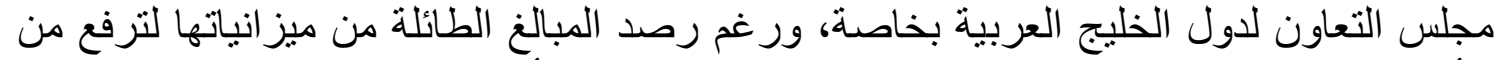

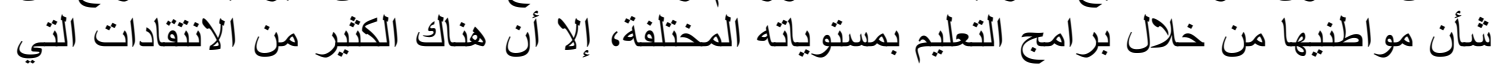

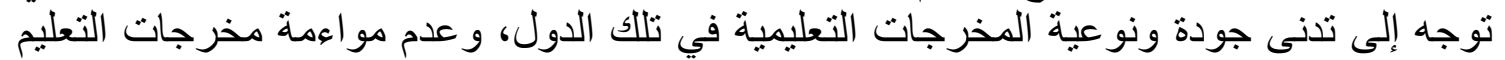

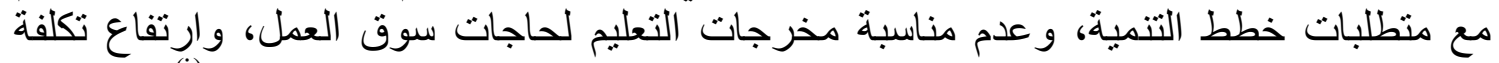
التعليم في ضوء معدلات التضخم العالية وزيادة الهدر التربوي في المؤسسات التعليمية)

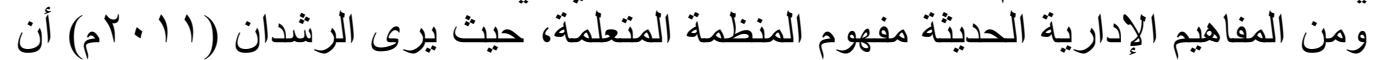

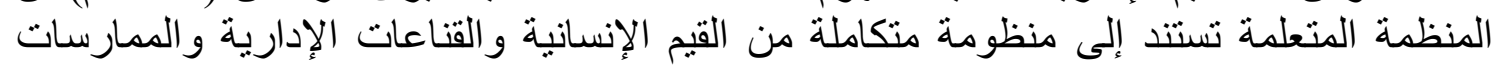

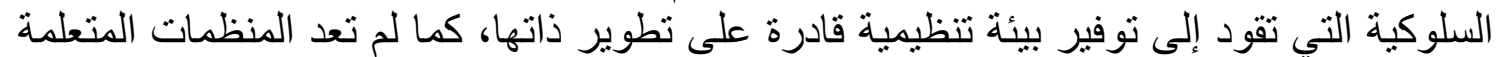

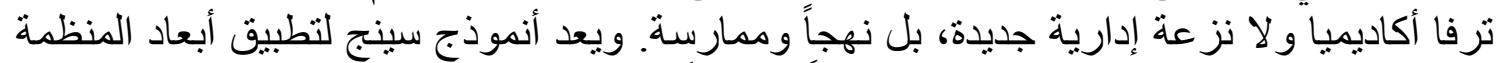

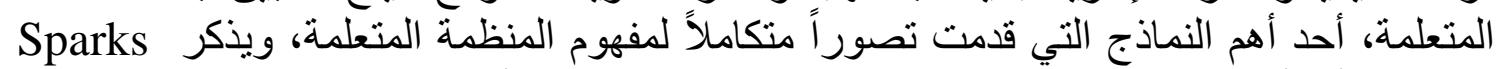
(2002) أن أفكار عالمِ الإدارة بيتر سينج Peter Senge قد أحدثت ثورة في مفهوم المنظمة

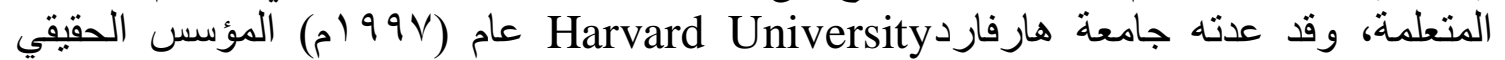

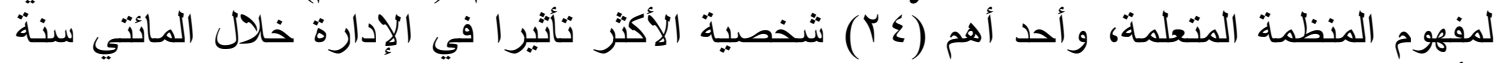

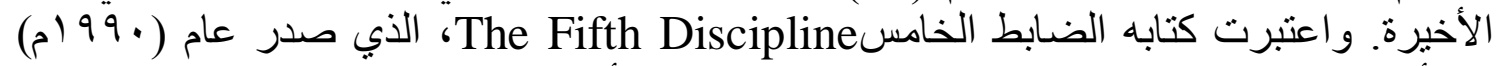

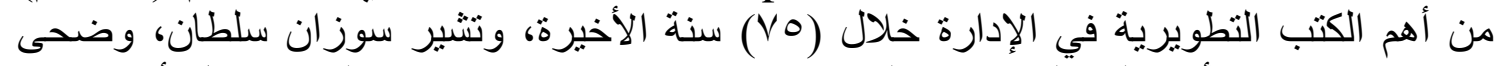

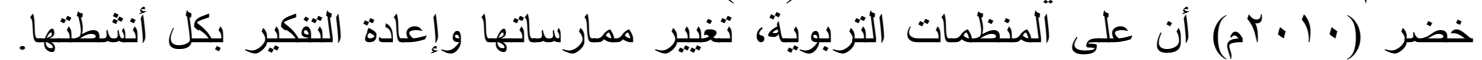

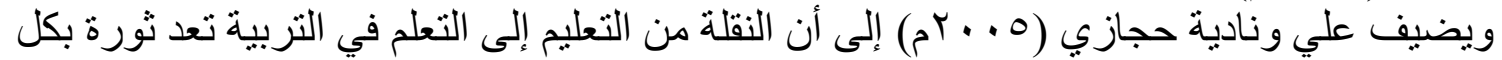

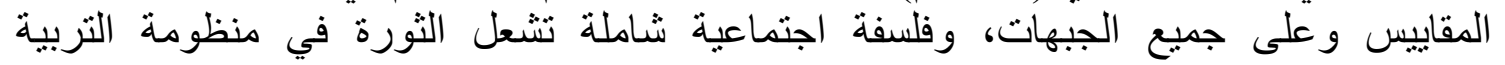
بمستوياتها كافة.

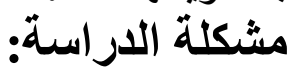

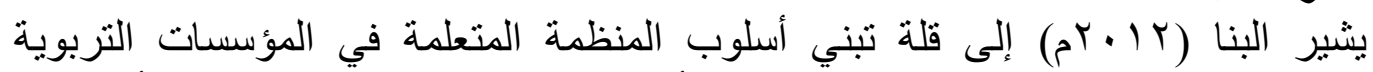

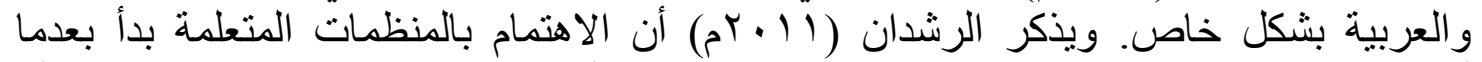

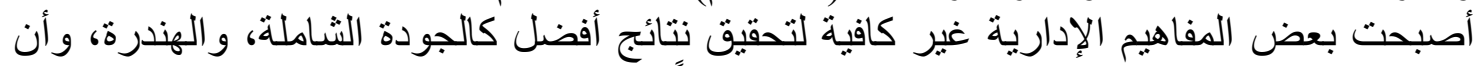

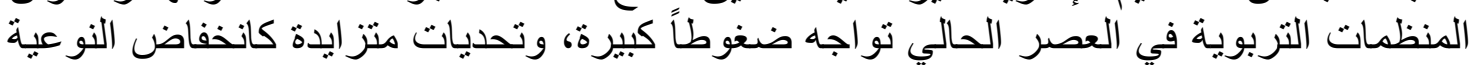

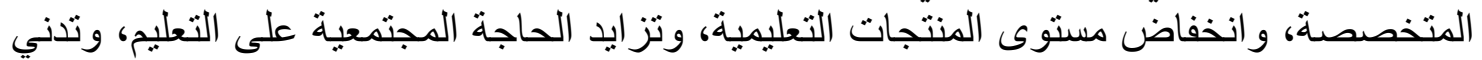
مستوى الرضا لأى العاملين.

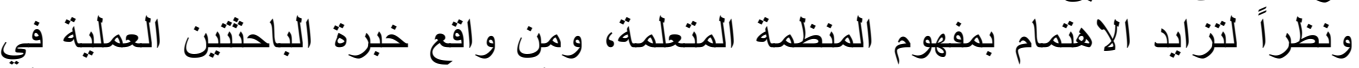

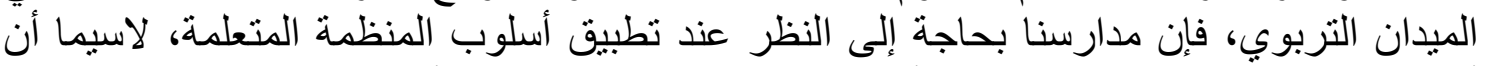

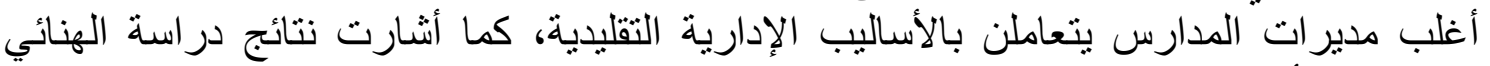

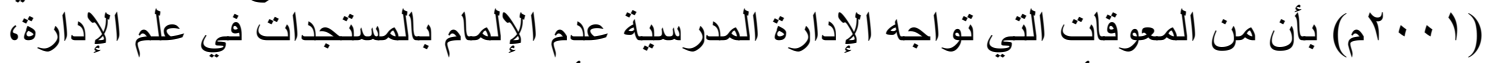

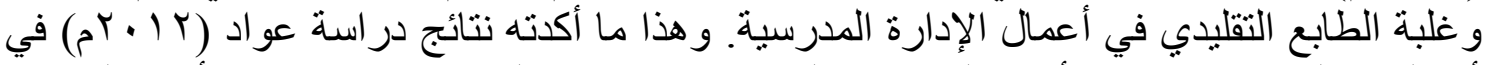
أن النهج البيروقراطي من أبرز المعوقات التي تواجه الإدارة المدرسية عند تطبيق أبعاد المنظمة

$\left({ }^{2}\right)$ Soina Blandford: Managing Professional Development In School, Routledge Press, London, 2000, P. 163. 
المتعلمة، في حين أن العديد من المنظمات حول العالَم تبنت مفاهيم جديدة. بناء على ذلك تتمثل

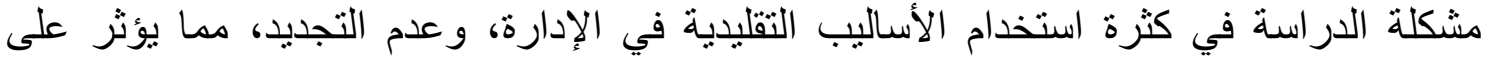
تطوير العملية التربوية، ومن الحلول المقترحة استخدام نماذج حديثة في الإدارة تسهم في تحسين

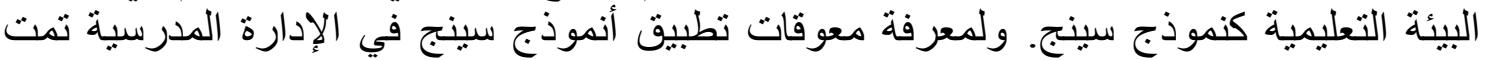
صياغة السؤال الرئيس التالي: التئي

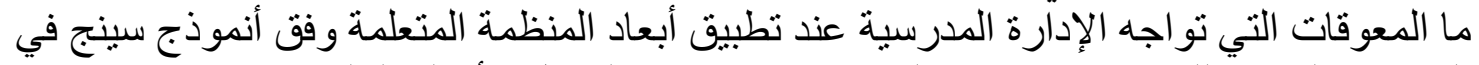

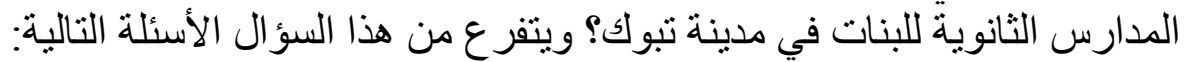

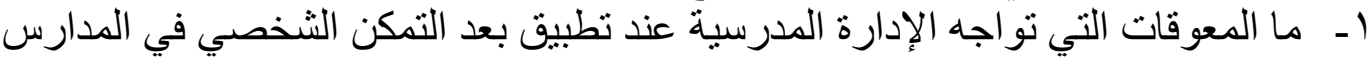

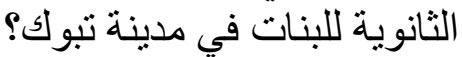

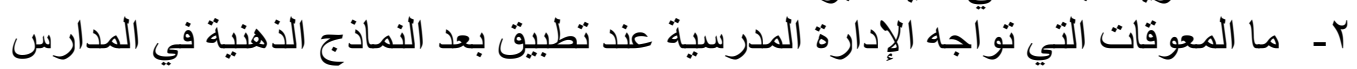

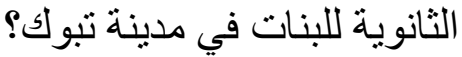

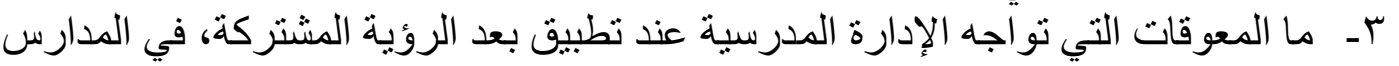

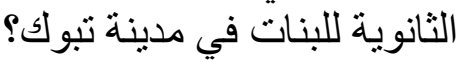
ـ ـ ما المعوقات التي تواجه الإدارة المدرسية عند تطبيق بعد تعلم الفريق في المدارس الثانوية

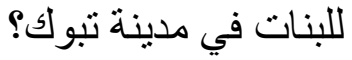
ــ ما المعوقات التي تواجه الإدارة المدرسية في تطبيق بعد التفكير النظمي في المدارس الثانوية

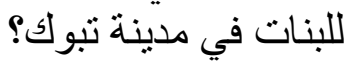

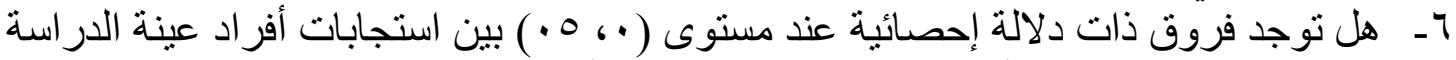

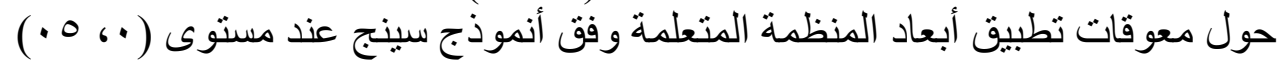
تعزى لمتغير (التخصص، عولى عدد سنوات الخبرة، الوظيفة الحالية)؟

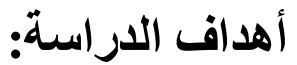

هدفت الدراسة إلى الكثف عن المعوقات التي تواجه الإدارة المدرسية عند تطبيق أبعاد المنظمة المتعلمة وفق أنموذج سينج في المدارس الثانوية للبنات في مدينة تبوك الإنه في الأبعاد التالية

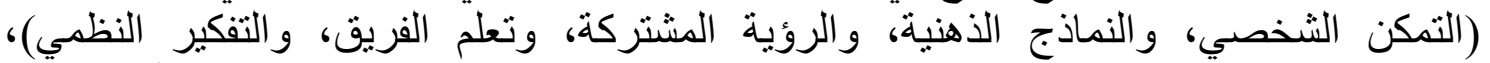

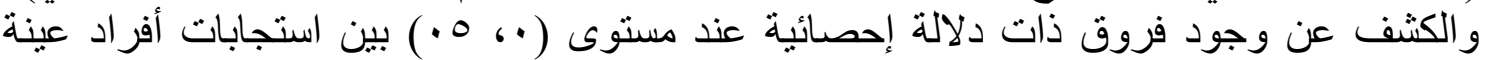

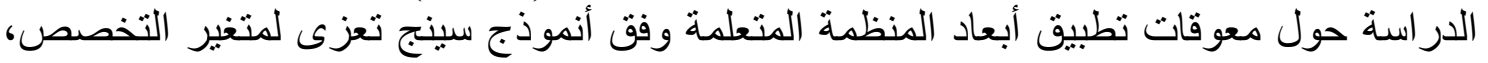

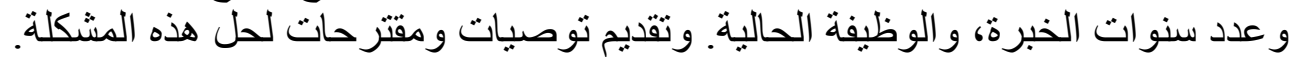

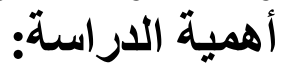

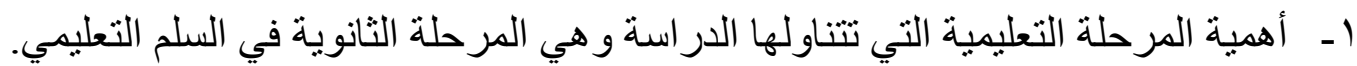

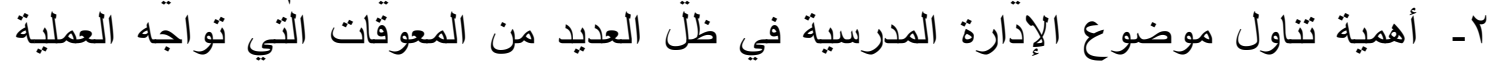

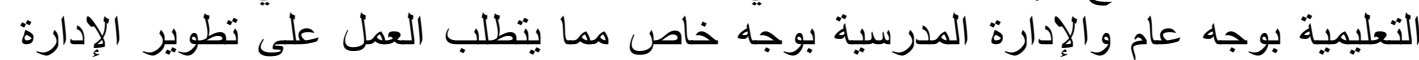

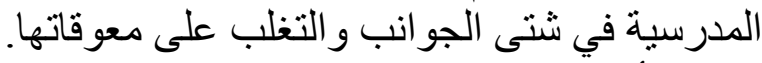

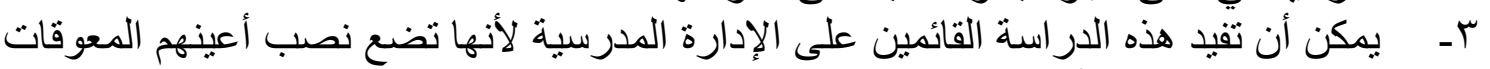

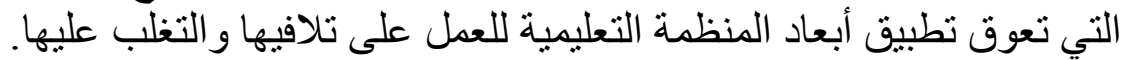
ع ـ التأكيد على دور المديرة القيادي في تطوير العملية التعليمية، والسعي إلى تطبية تطبيق أساليب إدارية حديثة.

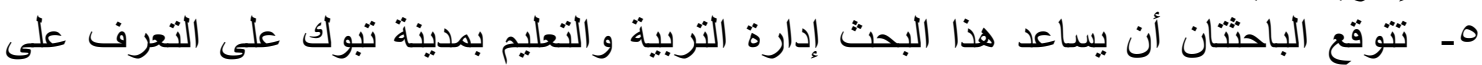

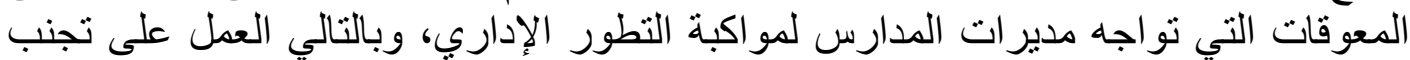
تللك المعوقات. اـ - تتز امن الدراسة مع سعي وزارة التربية والتعليم لتطوير التعليم والنهوض به، من خلال مشروع الملك عبد الله لتطوير التعليم العام. 


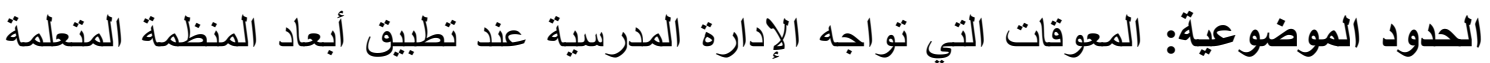

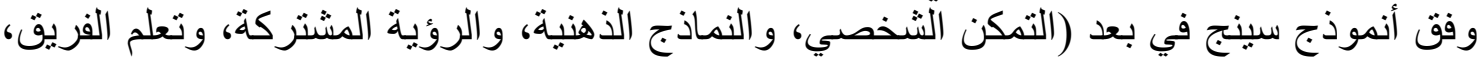

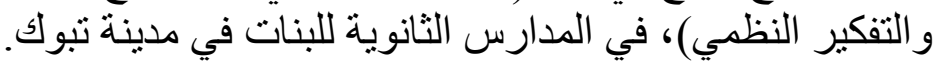

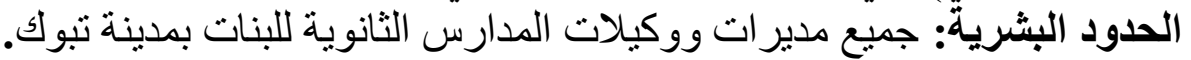

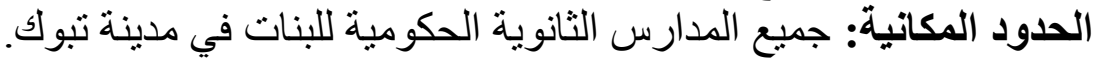

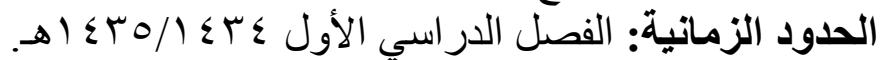

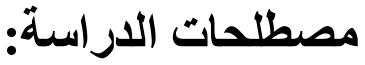

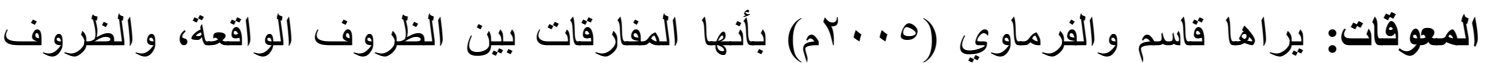

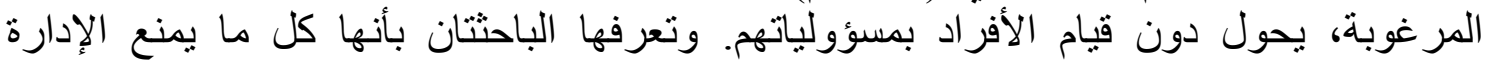
المدرسية من تحقيق أبعاد المنظمة المتعلمة.

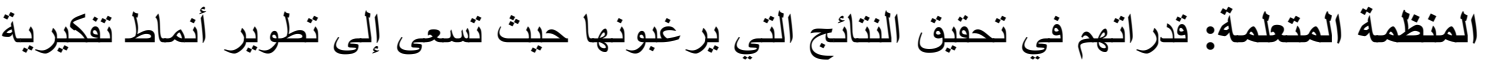

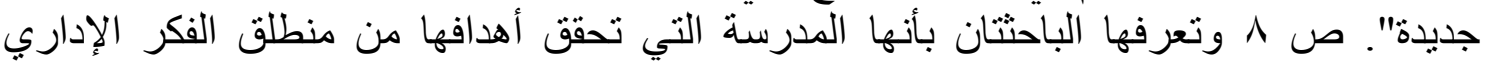

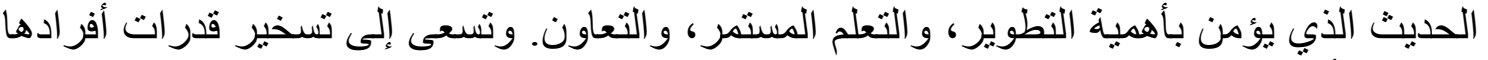

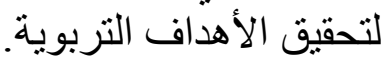

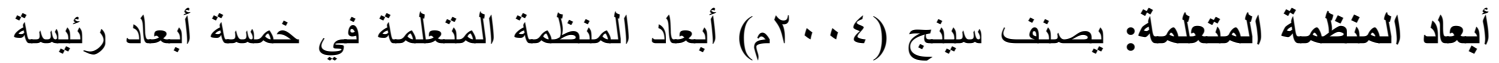

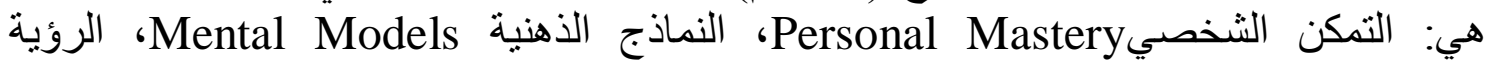
المشتركة Shared Vision، تعلم الفريق Team Learning، والتفكير النظمي System

.Thinking

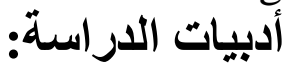

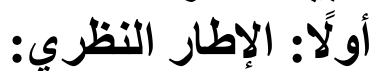
الإدارة الإطدرسية النظية

تطور مفهوم الإدارة الددرسية في عصرنا الحاضر؛ بفضل تطبل تطور الدفاهيم في ميادين

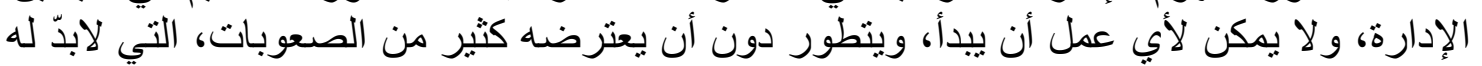
أن يتجاوز ها، ويعمل على تلأليلها. مفهوم الإدارة المدرسية: ماندية

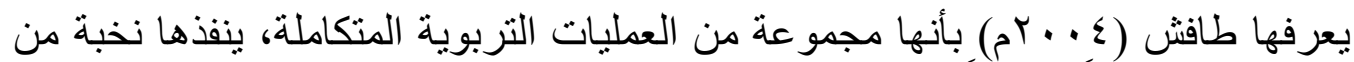

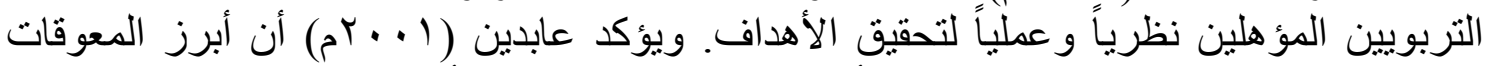

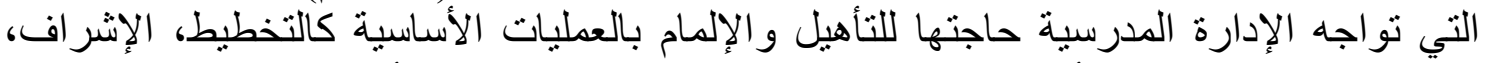

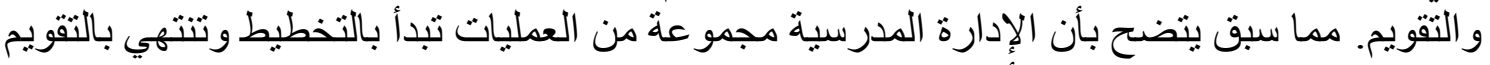
تنتباها الإدارة الدرسية لتحقق أهدافها. أهداف الإدارة المدرسية:

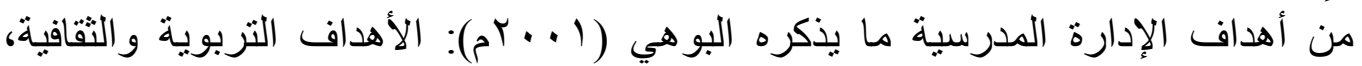

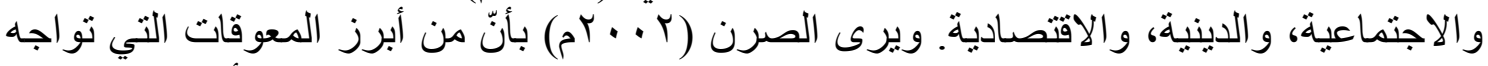

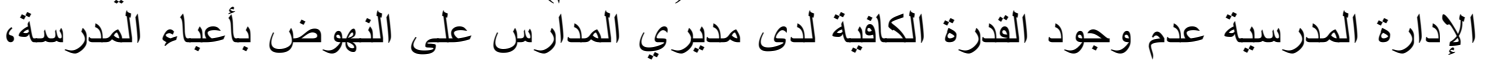

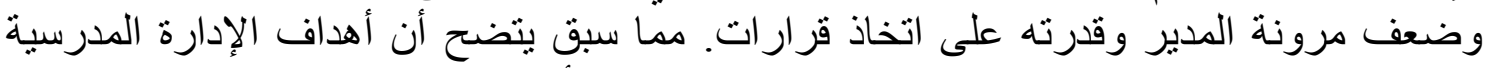
تتمثل عند تطبيق سياسة التربية و التعليم، و العمل على تحلى تحقيق أهدافيها. وظائف الإدارة المدرسية:

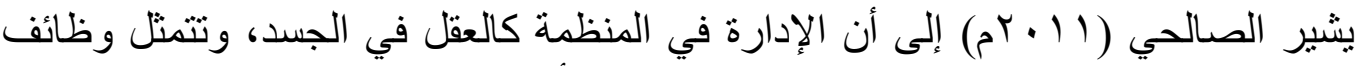

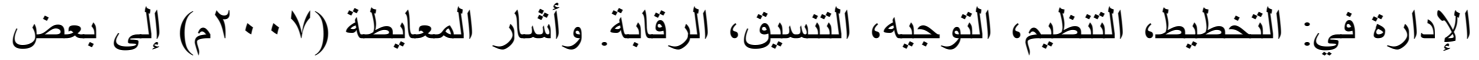


المعوقات التي تحد من أداء الإدارة، كنقص التعاون والتتسيق بين المعلمين، وقلة تبادل الخبرات

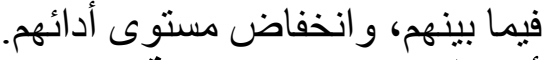

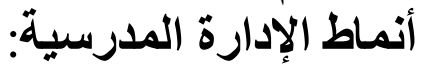

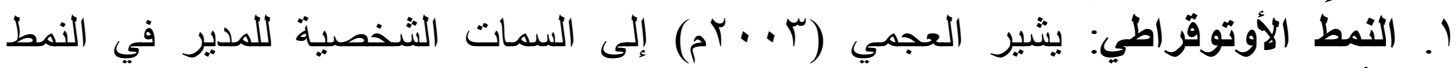

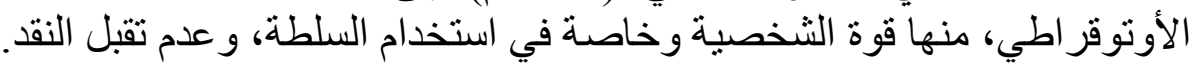

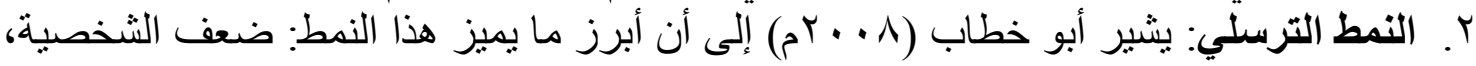

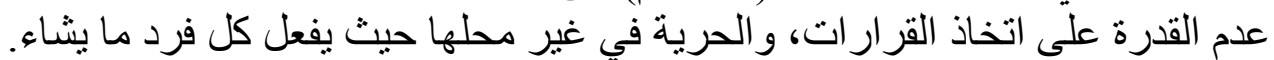

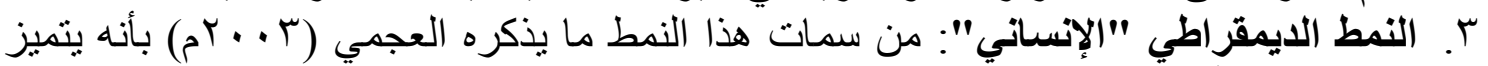

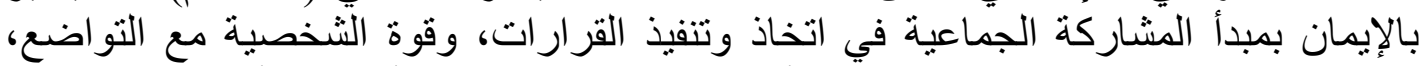

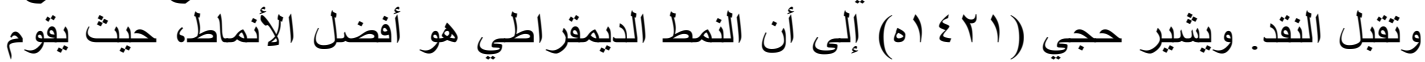

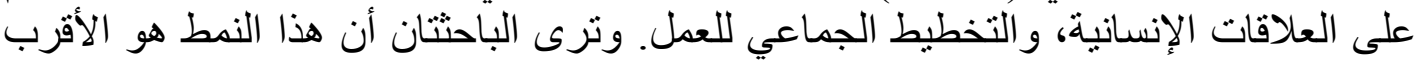

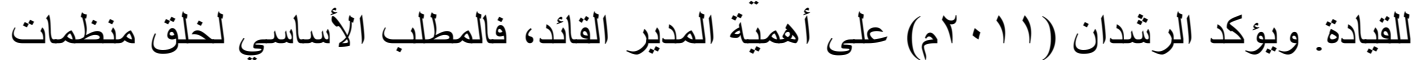

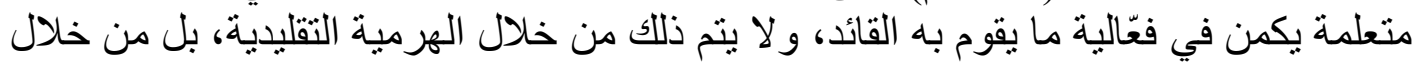

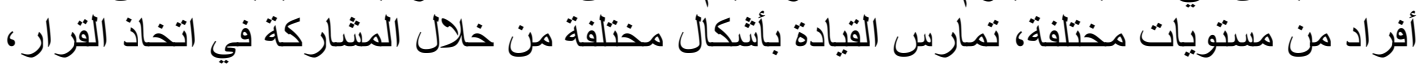

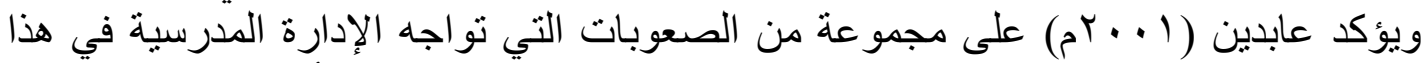

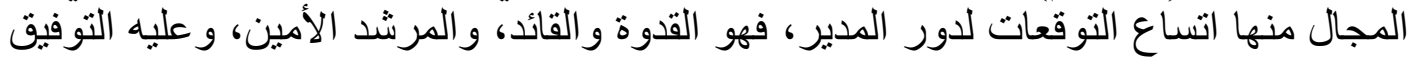
بين المهام الإدارية و الفنية.

المنظمة المتعلمة: الإمبة

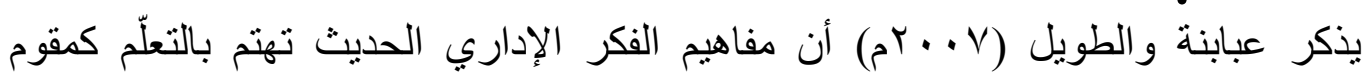

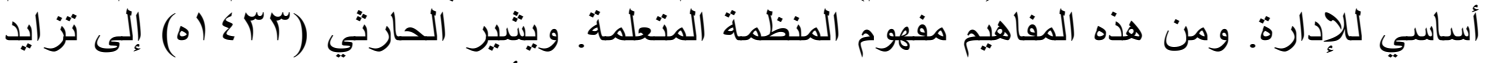

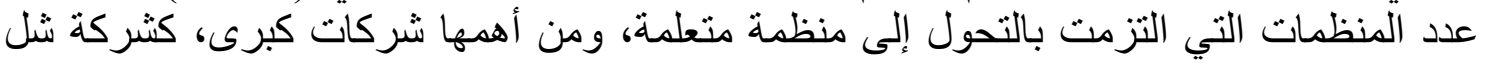

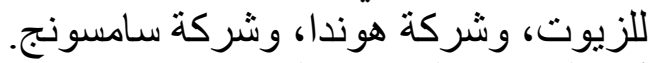

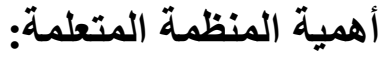

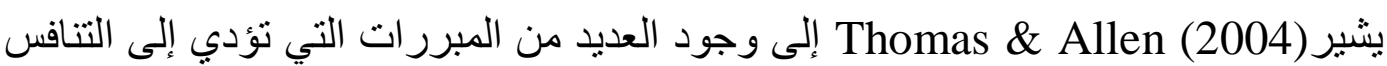

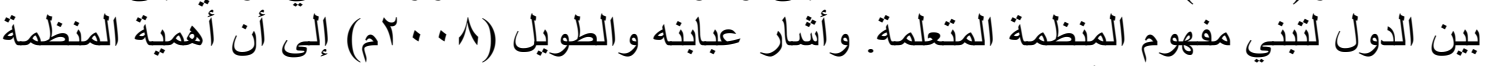

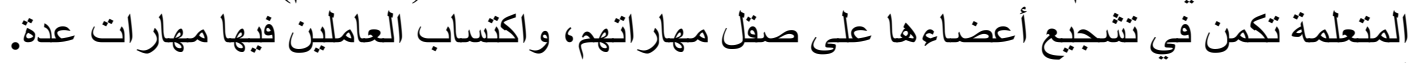

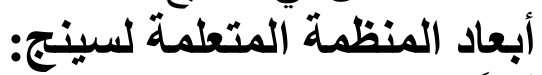

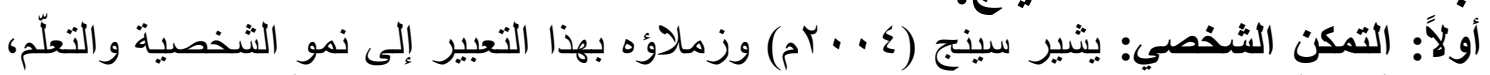

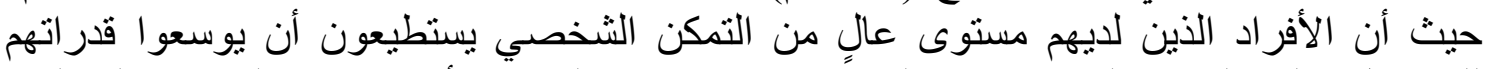

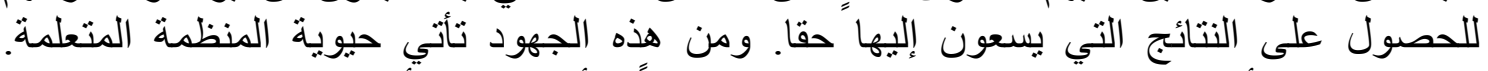

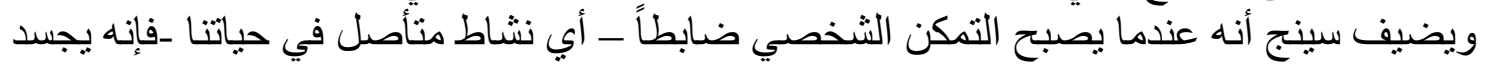

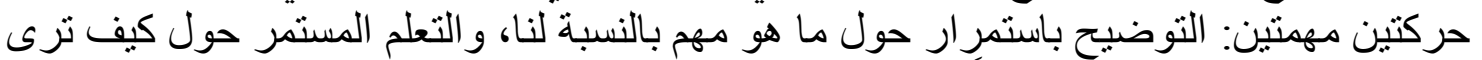

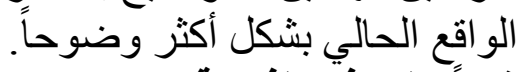

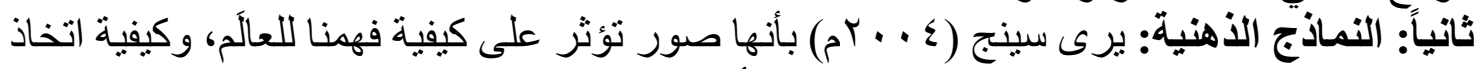

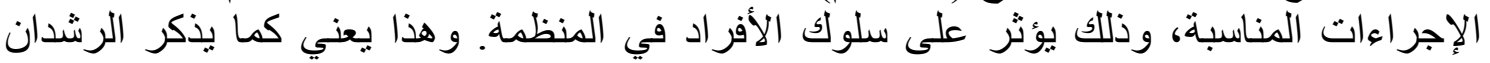

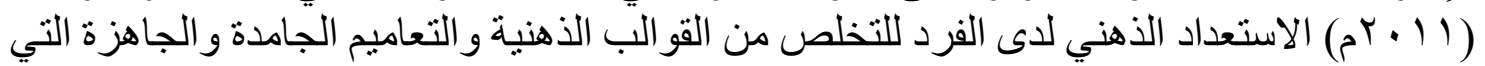

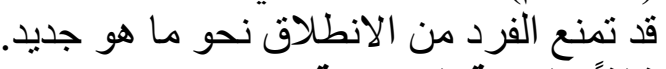

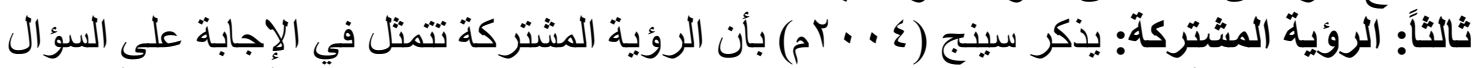

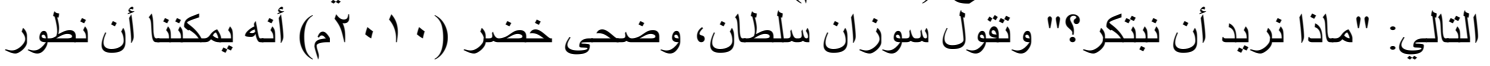

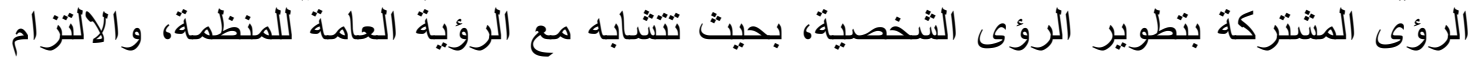
بالرؤية و العمل على تحقيقها. 


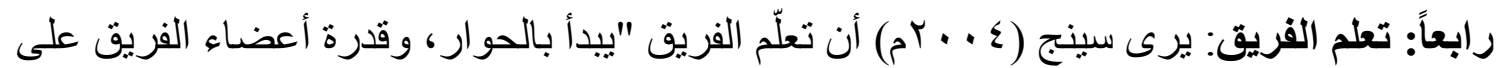

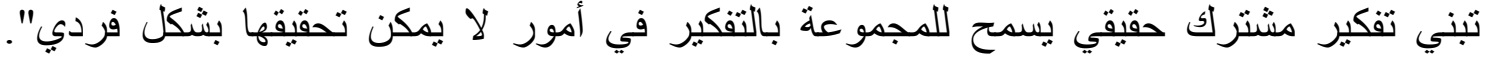

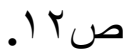

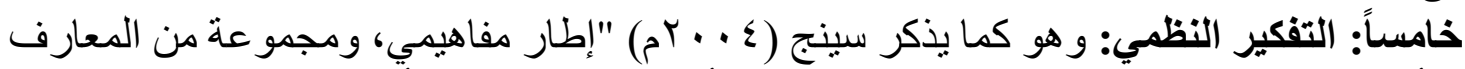

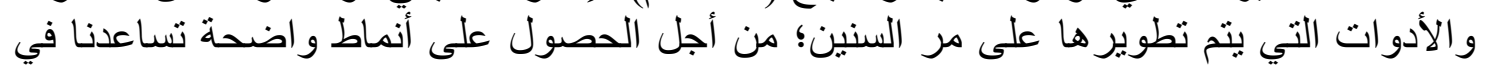

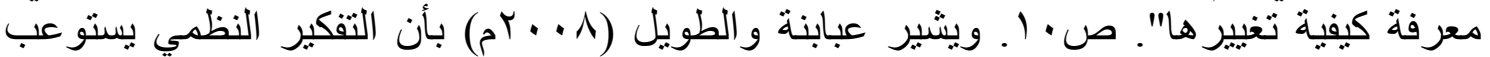

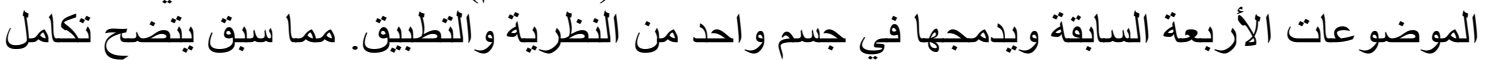

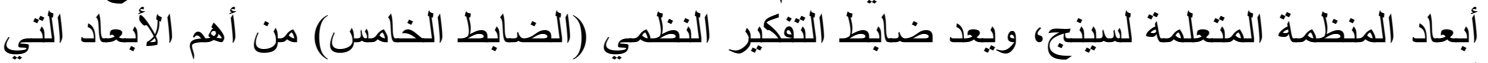

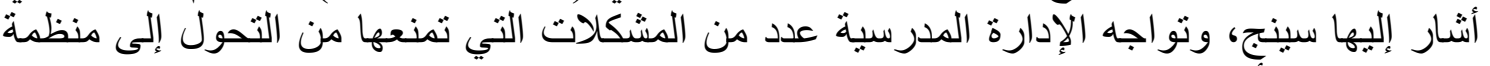

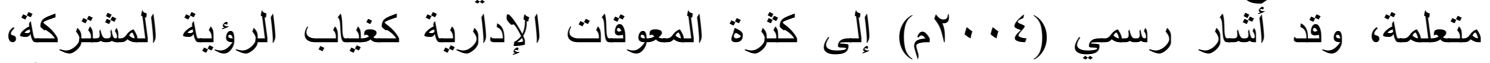

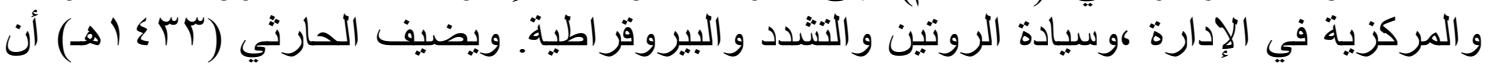

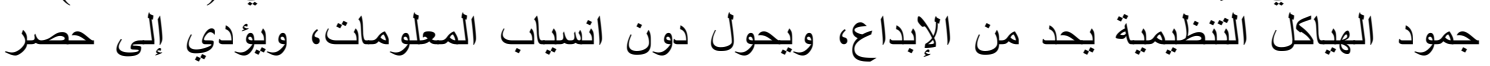

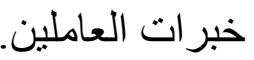

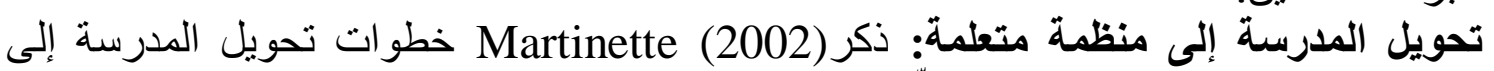

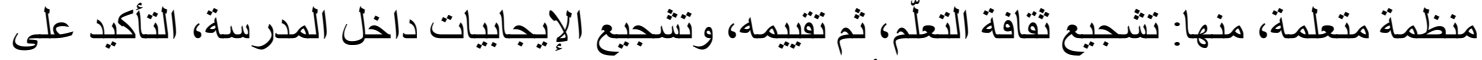

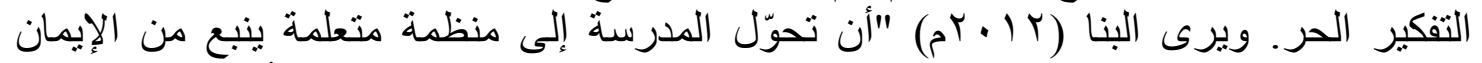

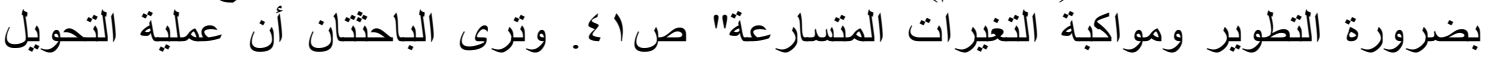

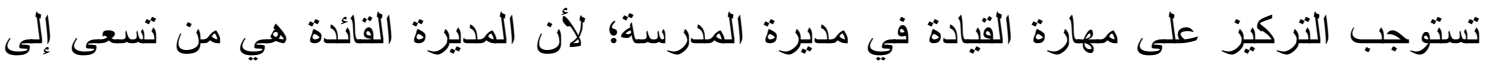

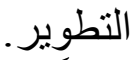

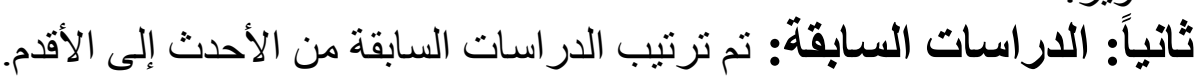

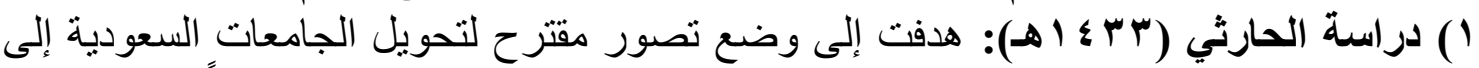

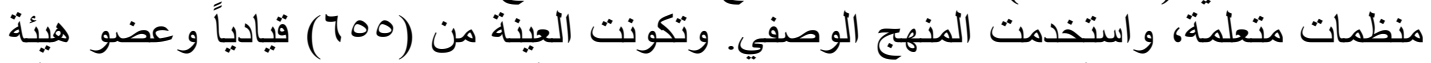

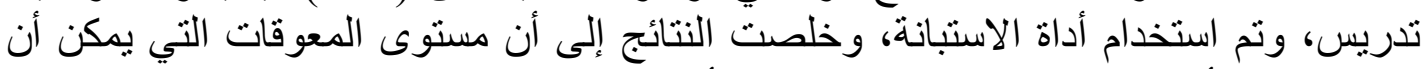

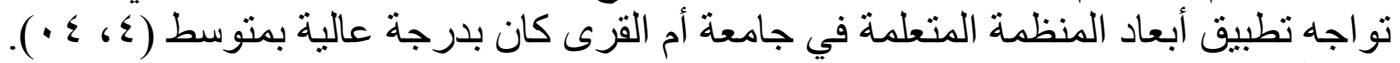

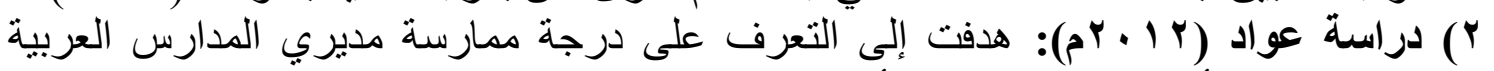

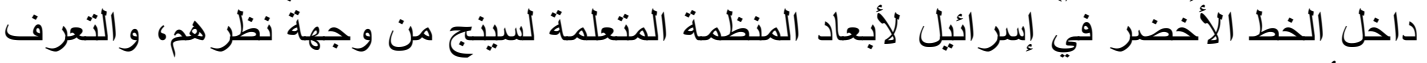

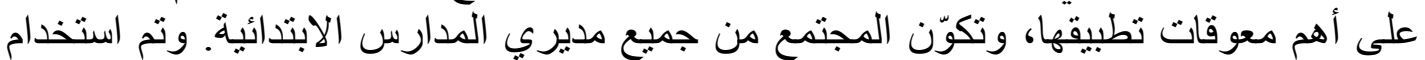

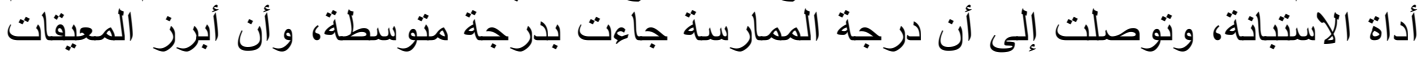

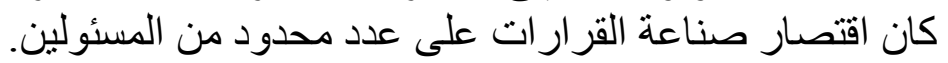

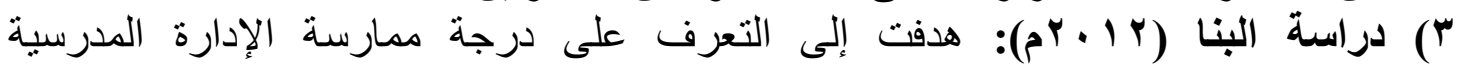

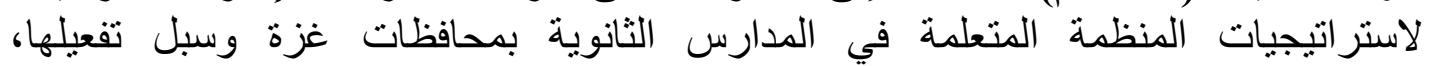

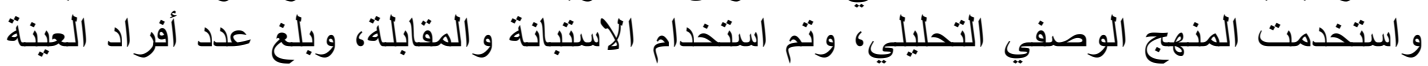

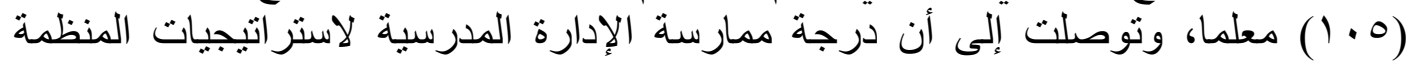

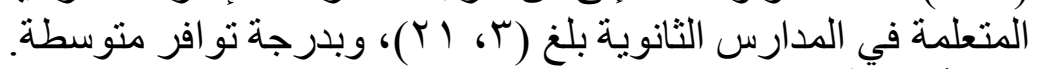

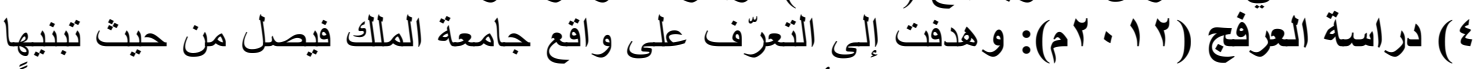

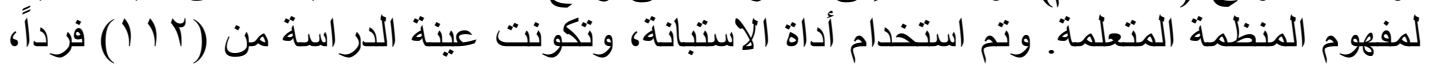

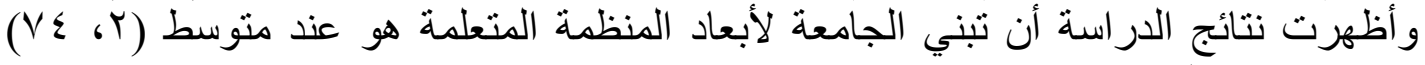
وبدرجة منوسطة.

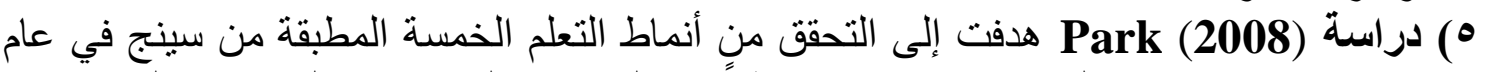

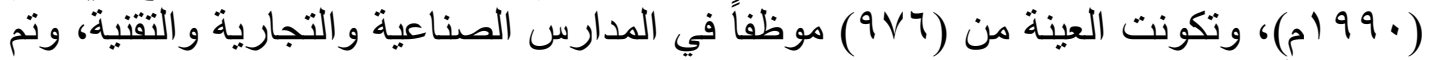
استخدام أداة الاستبانة، وقد دعمت نتائج الدراسة نظرية المنظمة الدتعلمة و الدفاهيم المرتبطة 
بها و التي تماتلها في المنظمات الغربيّة، والتي يمكن تطبيقها على المدرسة الكورية وتعكس 1النقافة الآسيوية.

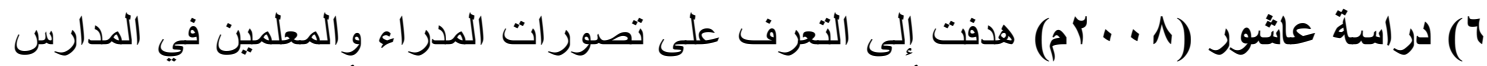

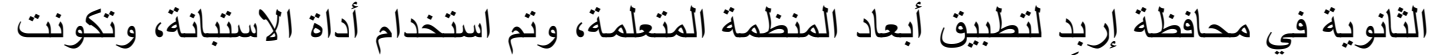

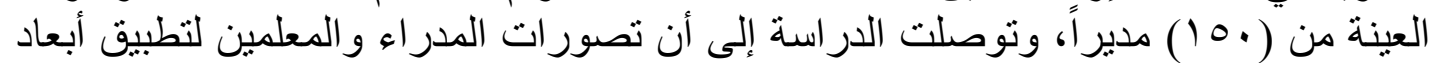

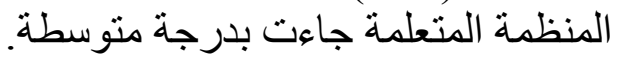

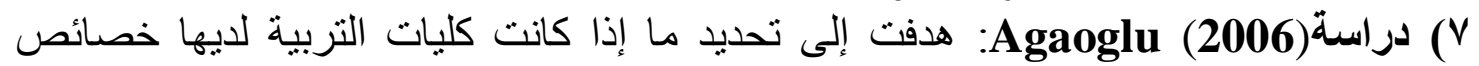

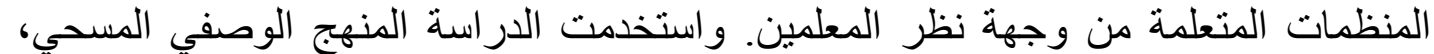

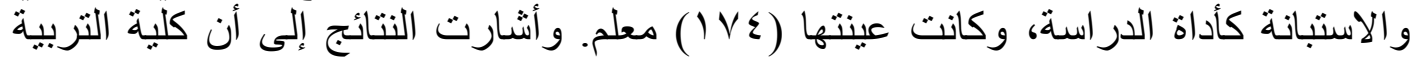

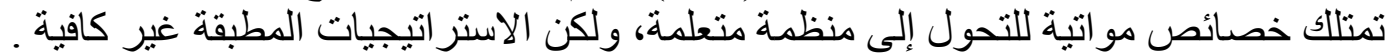

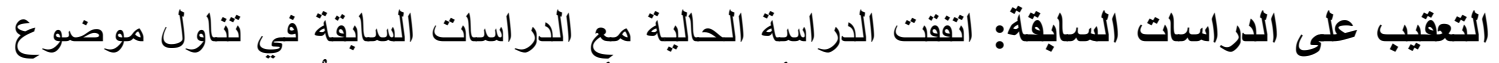

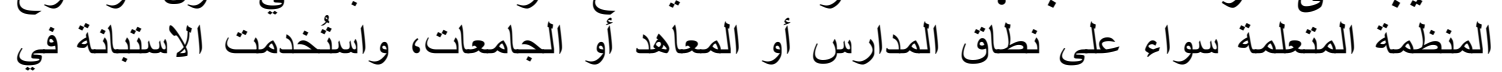

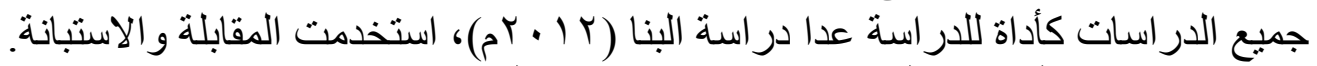

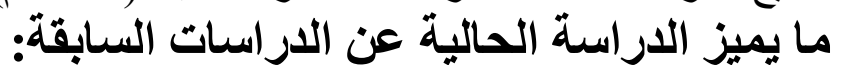

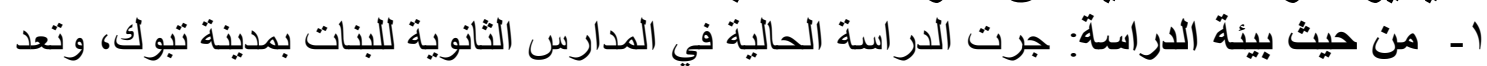

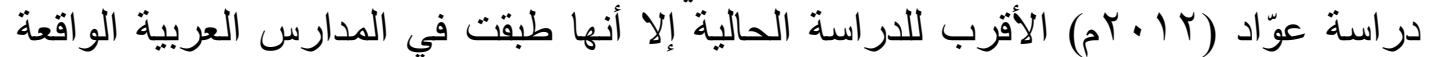

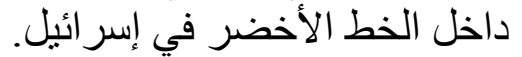

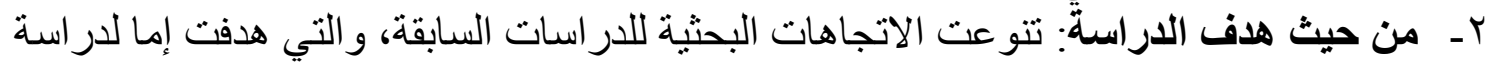

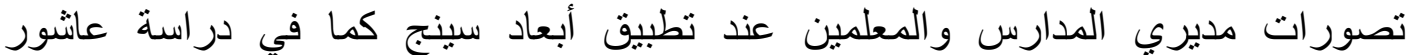

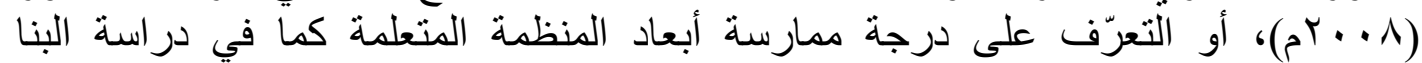

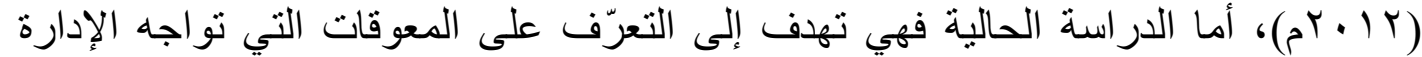

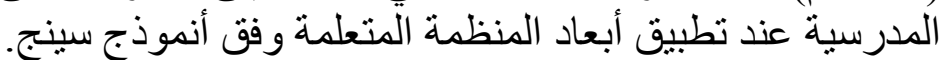

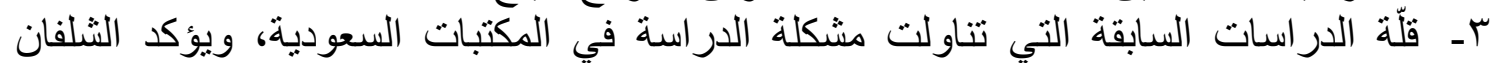

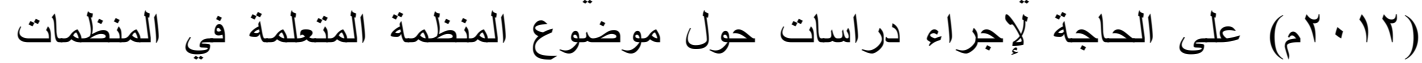
الحكومية في المملكة العربية السعودية.

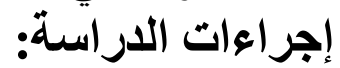

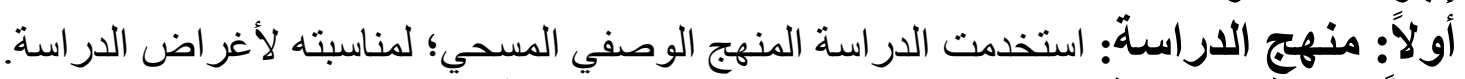

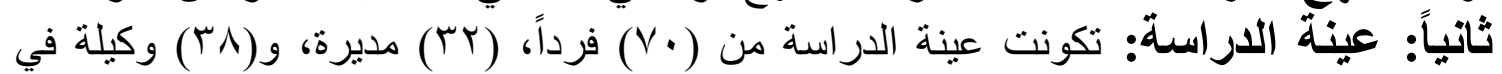

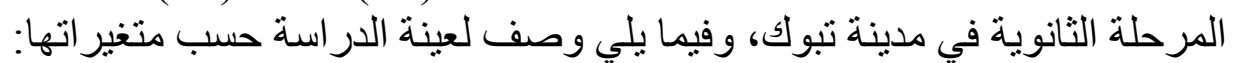

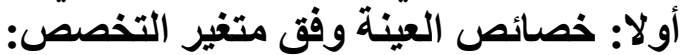
جدول (1) يوضح توزيع عينة الاراسة وفقا لمتغير التخصص

\begin{tabular}{|c|c|c|}
\hline النسبة المئوية & التكر ار & التخصص \\
\hline \% Q G & $\overline{T r}$ & علمي \\
\hline$\% 167 \mathrm{~V}$ & $\varepsilon V$ & أدبي \\
\hline$\% 1 \ldots$ & $v \cdot$ & المجموع \\
\hline
\end{tabular}

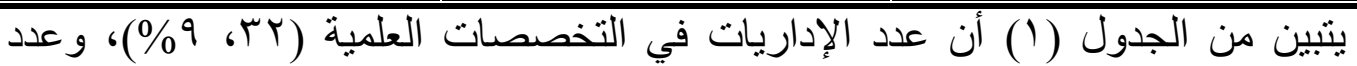

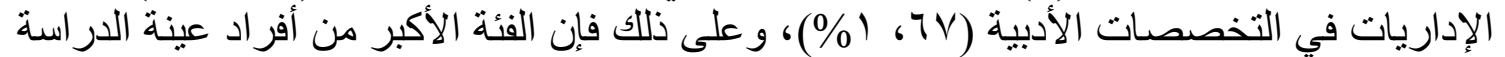

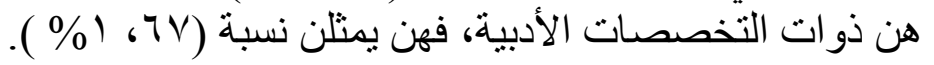


ثانيا: خصائص عينة الدراسة وفق متغير الوظيفة الحالية:

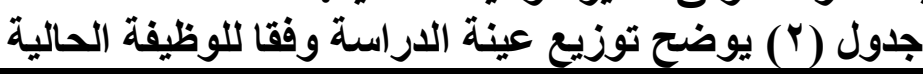

\begin{tabular}{|c|c|c|}
\hline النسبة العئوية & التكر ار & الوظيفة الحالية \\
\hline$\% \vee$ \ $\leqslant 0$ & Tr & مديرة \\
\hline$\% \Gamma, 0 \leqslant$ & ru & وكيلة \\
\hline$\% 1 \ldots$ & V. & المجموع \\
\hline
\end{tabular}

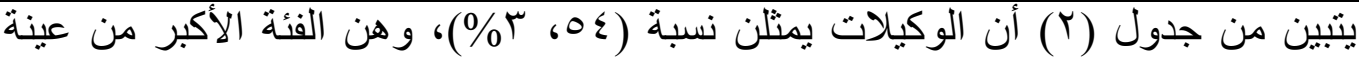

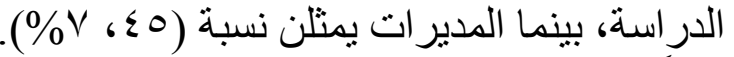

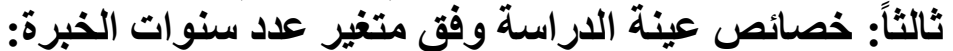

\begin{tabular}{|c|c|c|}
\hline النسبة المئوية & 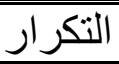 & عدد سنو ات الخبرة \\
\hline$\%$ \% ، & rq & أقل من خمس سنو ات \\
\hline$\% \vee$ V rO & 11 & من خمس إلى أقل من عشر سنوات \\
\hline$\% q^{0}$, & Tr & من عشر سنوات فأكثر \\
\hline$\% 1 \ldots$ & V. & المجموع \\
\hline
\end{tabular}

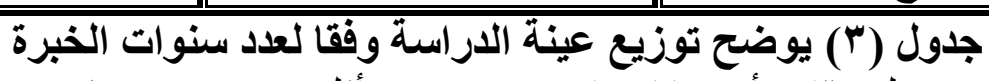

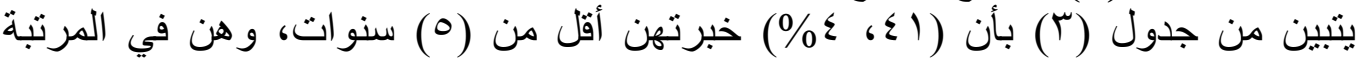

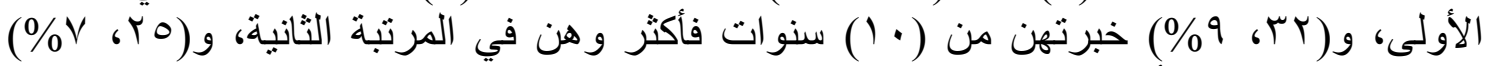

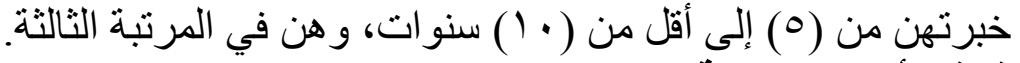

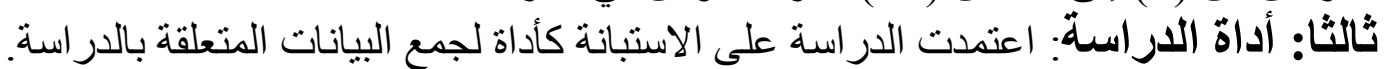

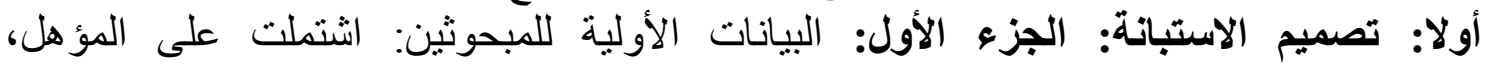

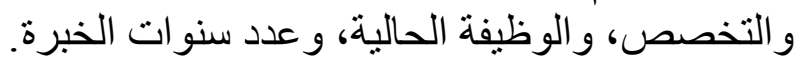

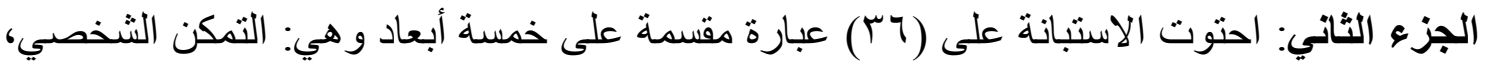

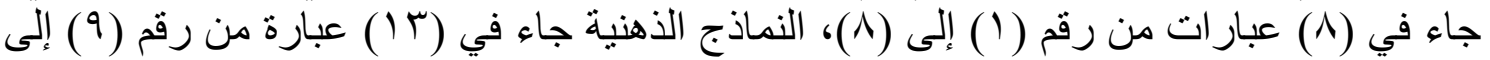

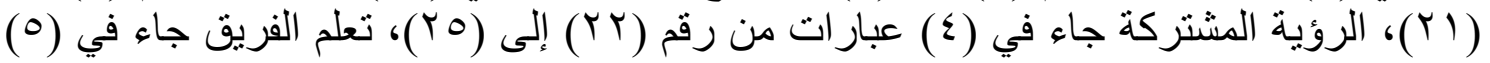

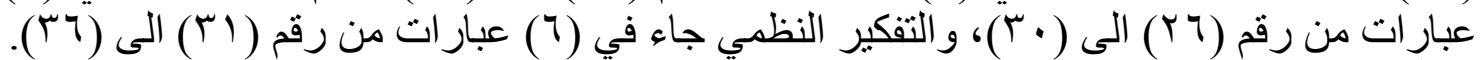

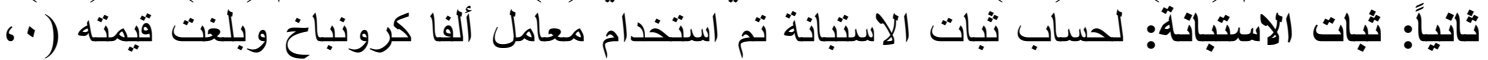

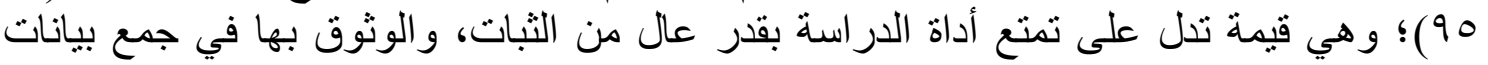

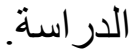

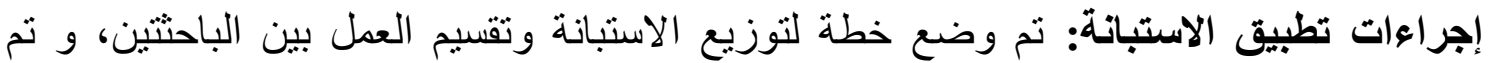

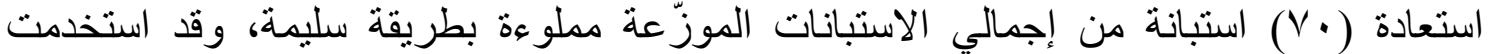

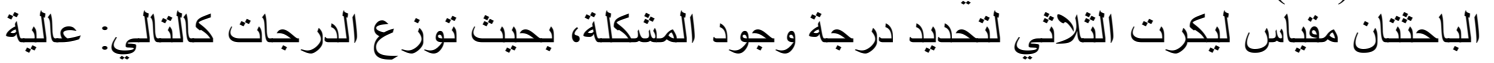

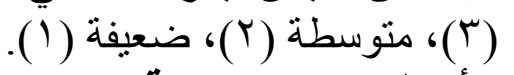

الأساليب الإحصائية: التكرارات والنية النسب المئوية لوصف العينة، ومعامل ارتباط بيرسون

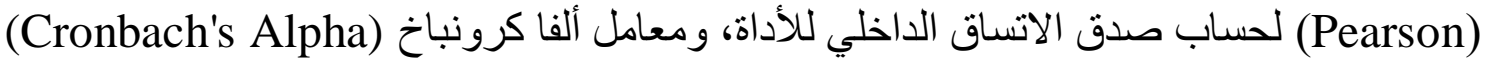

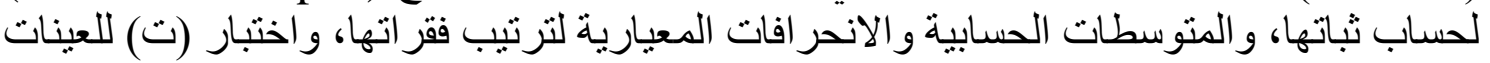

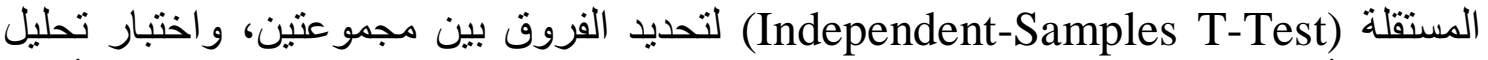
التباين الأحادي (ANOVA) لتحديد الفروق بين المجموعات ذات الثنات مستويات فئات فئكثر، واختبار (LSD) البعدي لتحديد اتجاهات الفروق في حالة وجودها عند استخدام تحليل التباين الأحادي. 
عرض وتفسير ومناقثة النتائج:

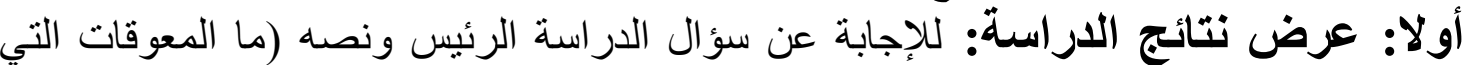

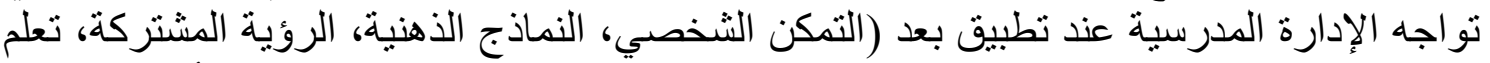

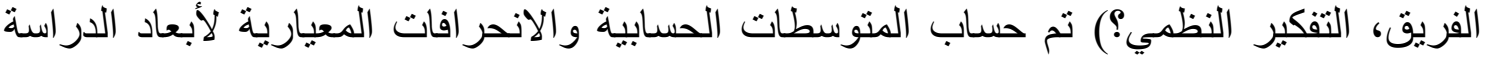

جدول (؛ ) المتوسطات الحسابية الإجمالية والانحر افات المعيارية لأبعاد المعوقات التي تواجه

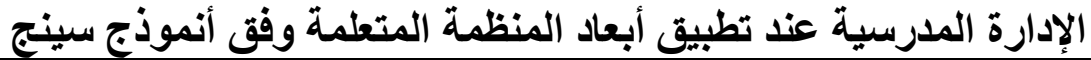

\begin{tabular}{|c|c|c|c|c|c|}
\hline الدرجة & الالنحر اف & الحسابي & الأبعاد & الترتيب & r \\
\hline منوسطة & $r \cdot,$. & 1164 & التمكن الشخصي & 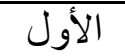 & 1 \\
\hline متوسطة & r. & .964 & التفكير النظمي & الخامس & r \\
\hline منوسطة & ґ 。. & - $\leqslant 64$ & النماذج الذهنية & الثاني & r \\
\hline متوسطة & or ، . & $\cdots 6 r$ & الرؤية المشتركة & الثالث & $\varepsilon$ \\
\hline متوسطة & or 6. & 9061 & تعلم الفريق & 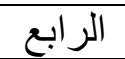 & 0 \\
\hline متوسطة & Tะ،. & - E 6 & \multicolumn{3}{|c|}{ المتوسط العام لجميع الأبعاد } \\
\hline
\end{tabular}

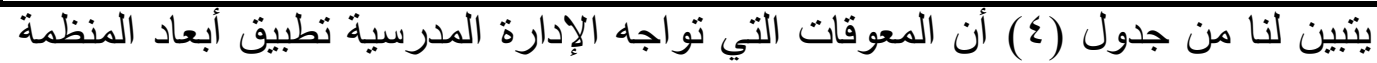

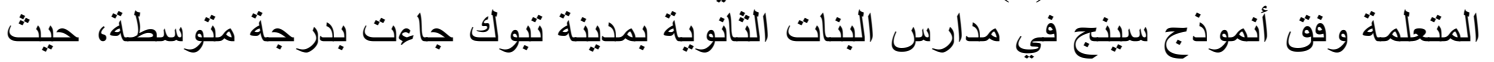

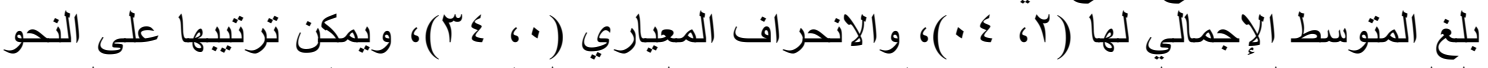

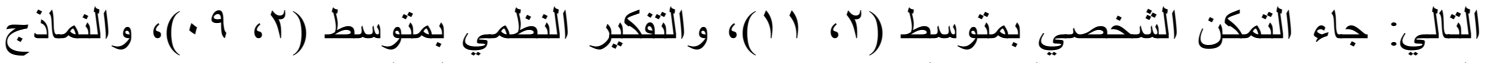

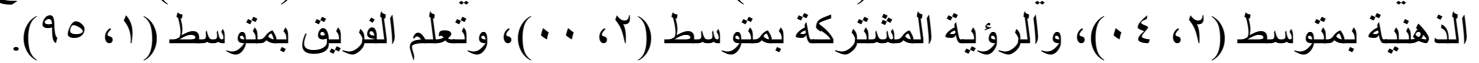

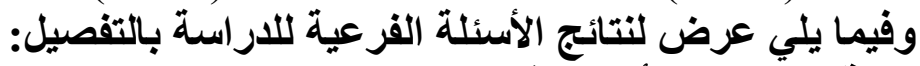

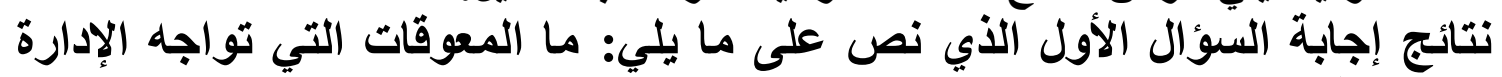

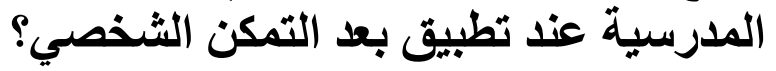

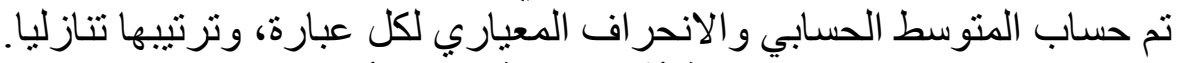
جدول (ه): استجابة أفراد العينة للبعد الأول (التمكن الثخصي)

\begin{tabular}{|c|c|c|c|c|c|}
\hline 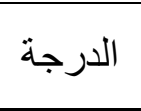 & الانعر افياري & الحسابي & 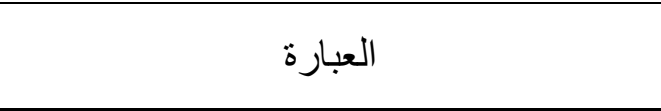 & العبارة & s \\
\hline عالية & $0 \wedge 6$ & $T \leqslant$ r & عقد الدور ات التدريبية لا يحدث بشكل مستمر. & $\mu$ & 1 \\
\hline 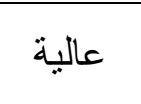 & 706. & $r \varepsilon, r$ & كثرة المهام الملقاة على عاتق مدير ات المدونة & 0 & r \\
\hline متوسطة & 076 & $T T_{6}$ & نقص الوسائل التعليمية الحديثة. & r & $r$ \\
\hline 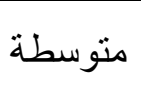 & $7 \leq 6$ & $116 r$ & تقليدية البر امج المقدمة في مركز التدريب الإدارة المدرسية. & 7 & $\varepsilon$ \\
\hline منوسطة & $V \cdot 6 \cdot$ & .964 & ضعف الرغبة في التعلم المستمر. & 1 & 0 \\
\hline 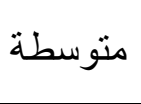 & 796 & .164 & 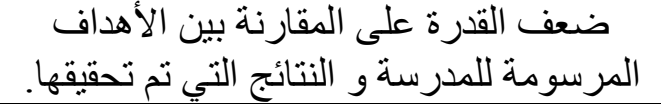 & $\wedge$ & 7 \\
\hline 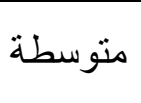 & 776 & 9461 & قناعة إدارة المدرسة بأن تبني المفاهيم الحديثة & $\varepsilon$ & V \\
\hline متوسطة & $7 \leq 6$ & 1161 & غموض أهداف العمل للغالبية & V & $\Lambda$ \\
\hline منوسطة & r. & 1164 & المتوسط العام & & \\
\hline
\end{tabular}


أفادت استجابات أفراد عينة البحث حول المعوقات التي تواجه إدارة المدارس الثانوية

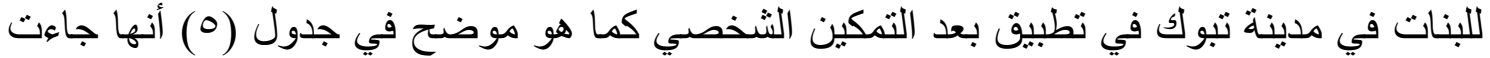

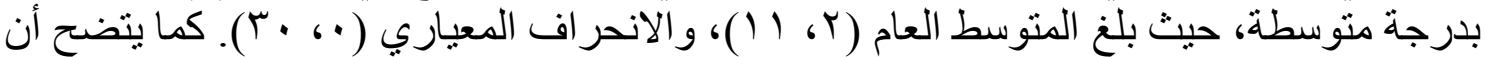

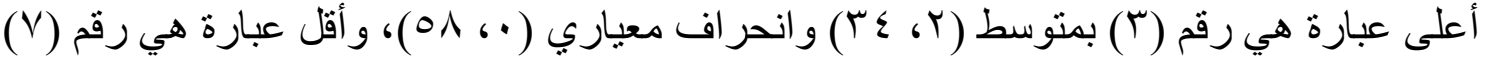

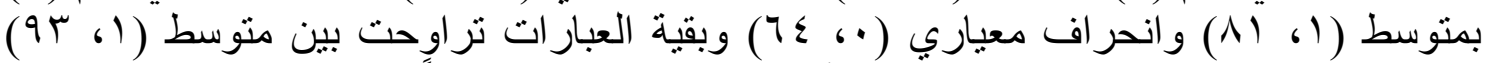

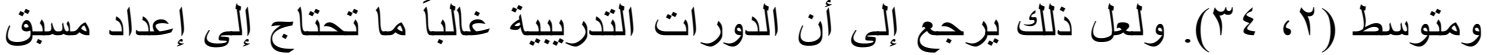

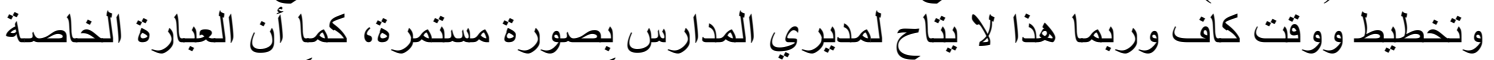

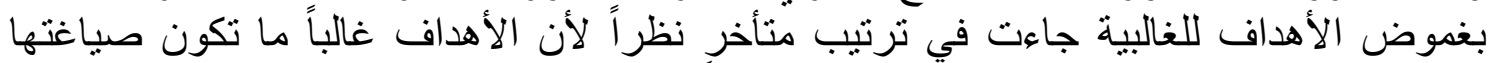

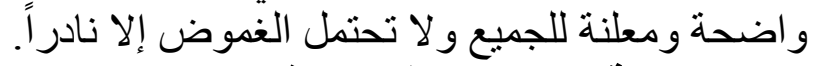

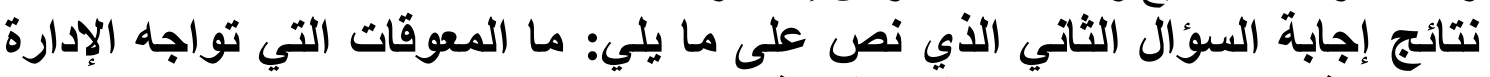

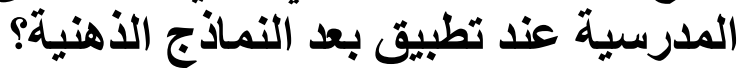
جدول (7) استجابة أفراد العينة للبعد الثاني ( النماذج الذهنية)

\begin{tabular}{|c|c|c|c|c|c|}
\hline 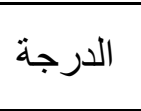 & 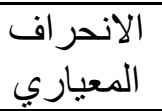 & 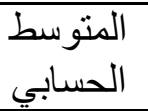 & 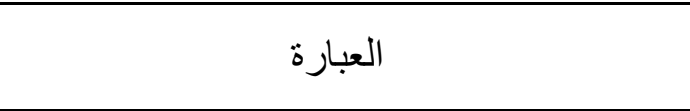 & 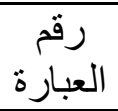 & s \\
\hline متوسطة & 716 & rq6r & اقتصـار عملية صنع القرار على المديرة فقط. & r & 1 \\
\hline متوسطة & 7.6 & $T \leq 6 r$ & اعتر اف المعلمات بأخطائهن يسبب لهن الحرج. & r & r \\
\hline 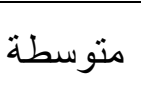 & 71, & r & قلة دورات تأهيل منسوبي الإدارة على استخدام & $\wedge$ & r \\
\hline متوسطة & $7 \cdot 6 \cdot$ & .964 & نقص العلم بالخبر ات الإدارية المتمبزة. & 7 & $\varepsilon$ \\
\hline 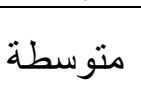 & 096. & $\cdot V 6 r$ & حرص الإدارة على التطبيق الحرفي للوائح و القين. & 1 & 0 \\
\hline 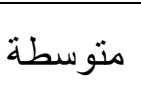 & 796 & .76 & حرية الر أي بين الإدارة والمعلمات أمر غير & 0 & 7 \\
\hline متوسطة & $V T_{6} \cdot$ & 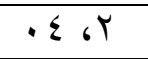 & قلة فاعلية الاجتماعات الدورية في تطوير العمل. & 11 & $\mathrm{~V}$ \\
\hline متوسطة & 706 & 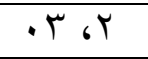 & تدني الدافعية الكافية للعمل. & 9 & $\Lambda$ \\
\hline متوسطة & 716 & $\cdots, r$ & قلة تقبل المعلمات للنقد الهادف من الإدارة. & 1 . & 9 \\
\hline متوسطة & 796 & 9961 & تدخل المعلمات في حل المشكلات يزيد من تفاقم & $\varepsilon$ & 1 . \\
\hline متوسطة & 706 & 9161 & محدودية التعاون بين المعلمات و الإدارة. & ir & 11 \\
\hline متوسطة & $V 76$ & 17.1 & غموض الرؤية العامة للمدرسة. & 14 & it \\
\hline 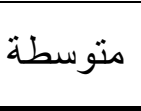 & Vo 6 & $V \leq 61$ & الاعتقاد السائد بأن التغيير سيؤدي إلى مخاطرة & V & M \\
\hline متوسطة & r余 6 & 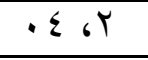 & المتوسط العام & & \\
\hline
\end{tabular}

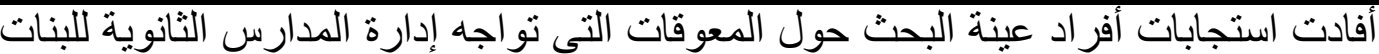

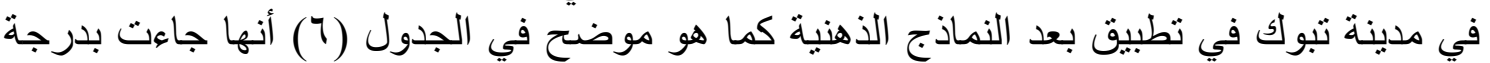

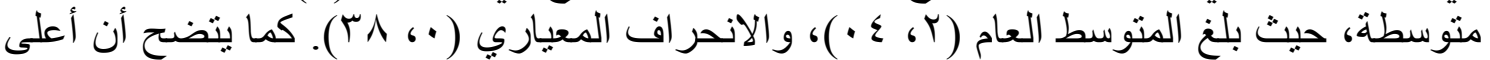

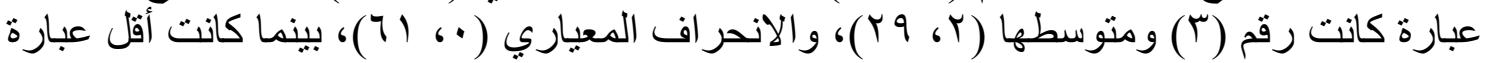

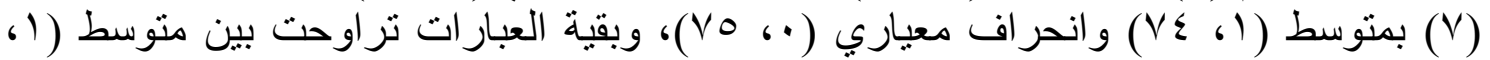

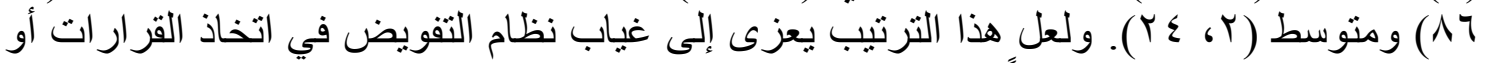

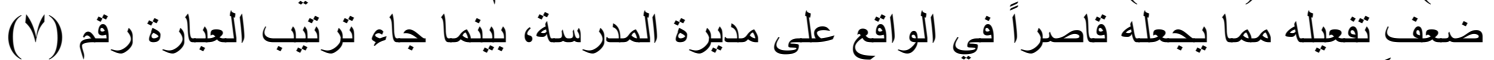

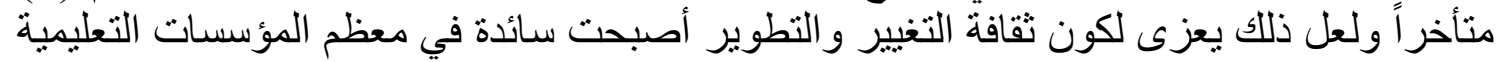
و الكل في الغالب على و وعي بها ور غبة في تطبيقها. 
نتائج إجابة السؤال الثالث الذي نص على مائي ما يلي: ما المعوقات التي تواجه الإدارة

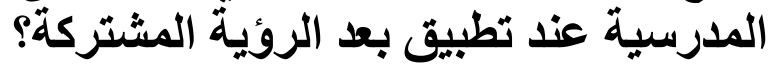

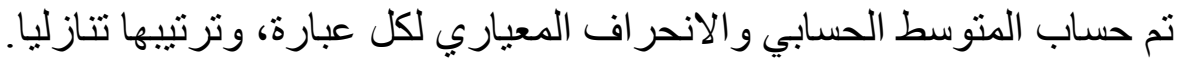

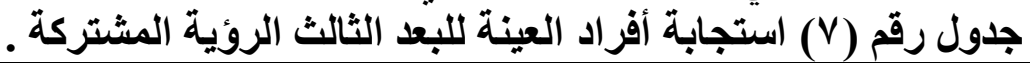

\begin{tabular}{|c|c|c|c|c|c|}
\hline الدرجة & 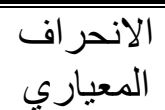 & ال المتوسطي & العبارة & 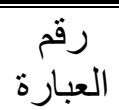 & 5 \\
\hline متوسطة & $\vee \cdot \ldots$ & $1 \cdot r$ & اقتصار نظرة المنسوبات على الوضع & r & 1 \\
\hline منوسطة & 。 & .16 & اقتصار بناء رؤية مستقبلية للمدرسة على & 1 & r \\
\hline متوسطة & vo.. & 9761 & شيوع الرؤية السليية لاى العاملين في & r & $r$ \\
\hline متوسطة & 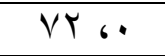 & $9 \pi, 1$ & غياب تقييم رؤية المدرسة. & $\varepsilon$ & $\varepsilon$ \\
\hline متوسطة & or ، & ? r r & المتوسط العام & & \\
\hline
\end{tabular}

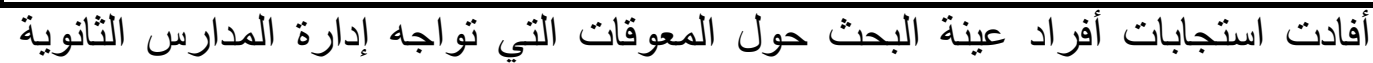

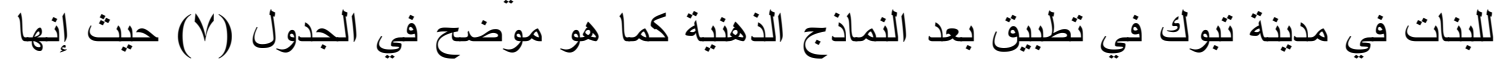

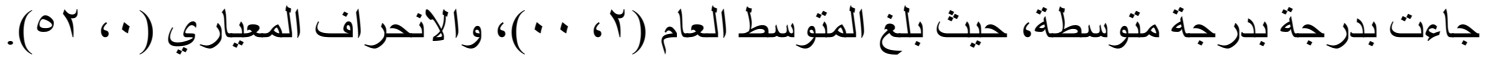

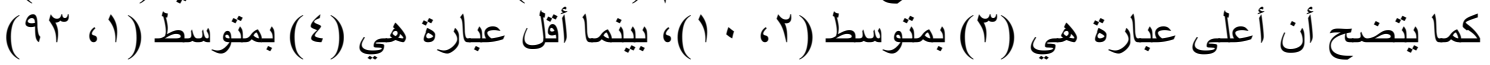

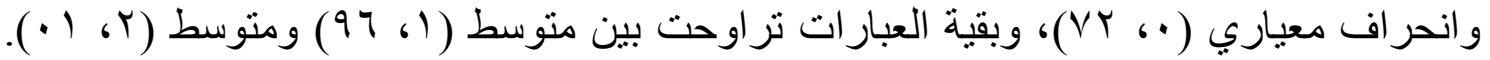

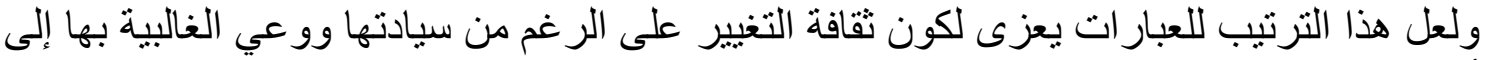

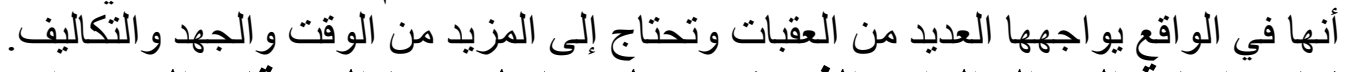

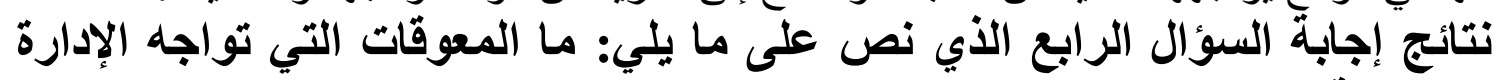

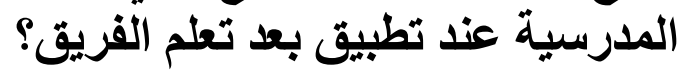

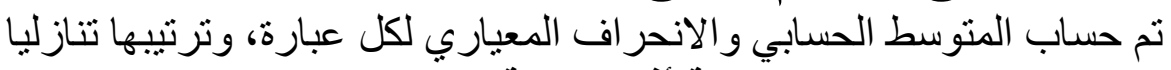
جدول (^) استجابة أفراد العينة للبعد الرابع تعلم الفريق.

\begin{tabular}{|c|c|c|c|c|c|}
\hline 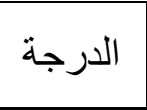 & المعياري & المتابي & العبارة & العبارة & r \\
\hline متوسطة & $\overline{l v \cdot ، \cdot}$ & $\bar{~}$ & ققلة تبادل الخبرات بين المعلمات. & $r$ & 1 \\
\hline متوسطة & 1) ، & ? r r & نقص تشكيل لجان أو فرق على مستوى & $\varepsilon$ & r \\
\hline متوسطة & Vo a. & 9761 & نقص الدعم و التحفيز للعمل الجماعي. & r & $r$ \\
\hline متوسطة & ים & 9 & غياب روح التعاون بين المعلمات في & 1 & $\varepsilon$ \\
\hline متوسطة & 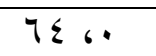 & A) 61 & ضعف دعم الإدارة الددرسية للعمل الجماعي. & 0 & 0 \\
\hline متوسطة & Or ،. & 9061 & المتوسط العام & & \\
\hline
\end{tabular}

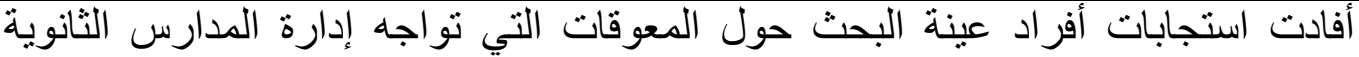

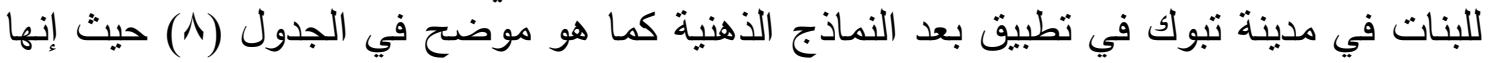

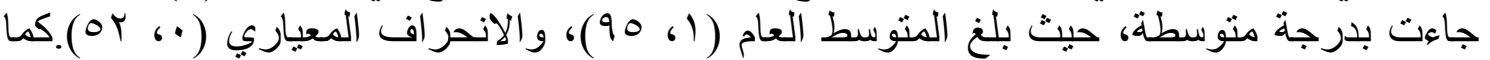

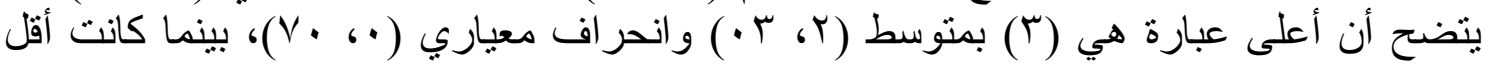

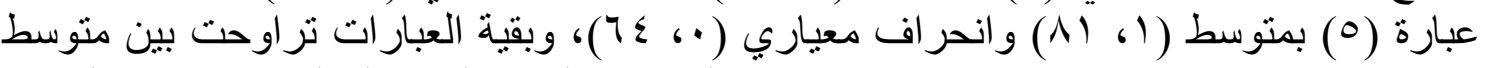

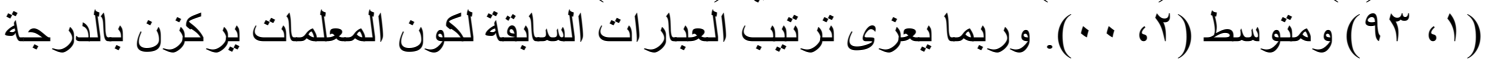




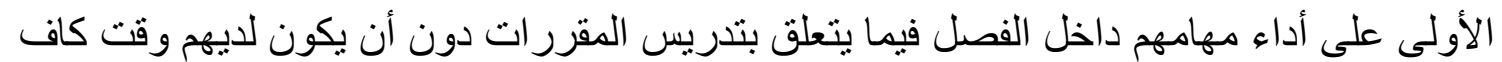

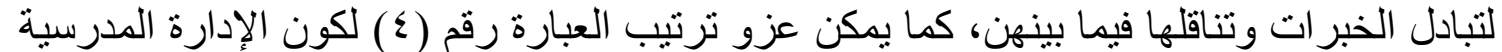

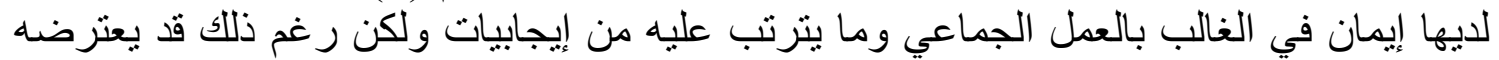
بعض العقبات كالتخطيط المسبق و التنظيم.

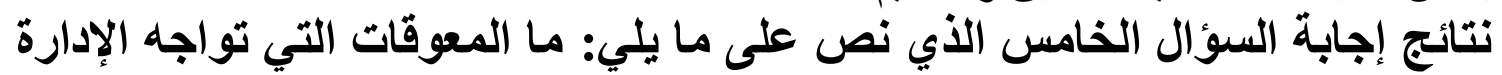

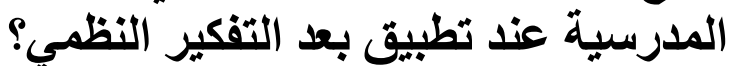

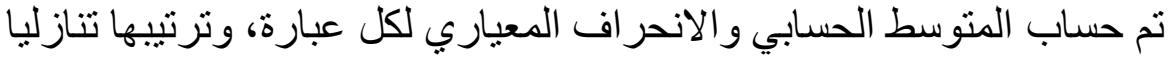
جدول (9) استجابة أفراد العينة للبعد الخامس التفكير النظمي.

\begin{tabular}{|c|c|c|c|c|c|}
\hline اللارجة & المعياري & المسابي & 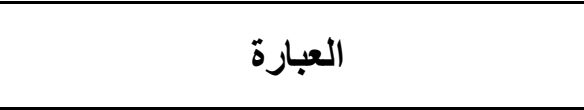 & 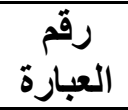 & p \\
\hline متوسطة & 774 . & Tq، r & ضيق الوقت يمنع مناقشة الأفكار الجديدة. & 0 & 1 \\
\hline متوسطة & $V V_{6}$ & 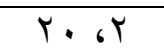 & الاهتمام بالمخرجات أكثر من العمليات. & r & $r$ \\
\hline متوسطة & $7 \cdot 6$ & .965 & أخذ التغذية الر اجعة ليس من المنسو بات. & $\Gamma$ & $r$ \\
\hline 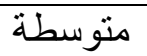 & $74 ،$ & $\cdot V_{6} r$ & التهرب من اتخاذ قرارات جريئة. & 1 & $\varepsilon$ \\
\hline متوسطة & $7 V_{6} \cdot$ & $9 \leqslant$ ، 1 & نقص الأساليب الدديثة لمو اكبة التغيرات. & 7 & 0 \\
\hline متوسطة & Tra & 94,1 & تأثتير الجو السائد في المدرسة سلبيا على الإبداع. & $\varepsilon$ & 7 \\
\hline متوسطة & r4، & .964 & المتوسط العام & & \\
\hline
\end{tabular}

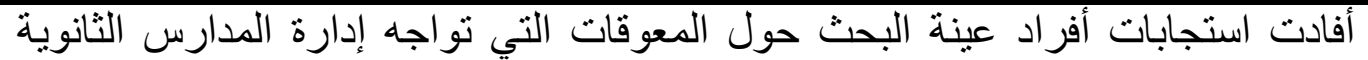

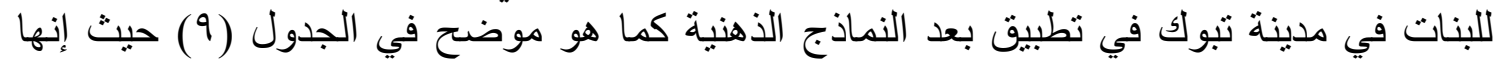

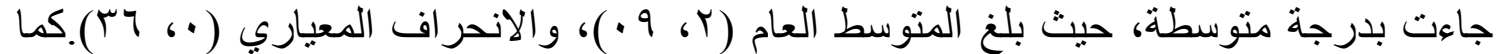

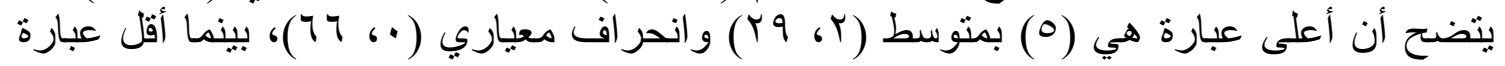

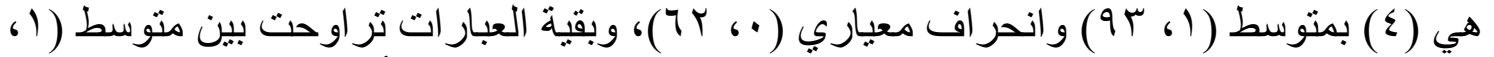

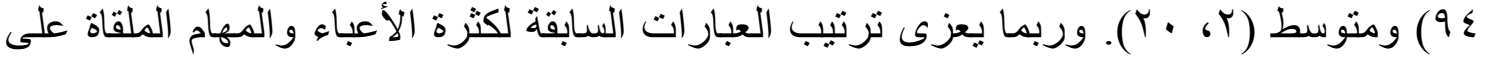

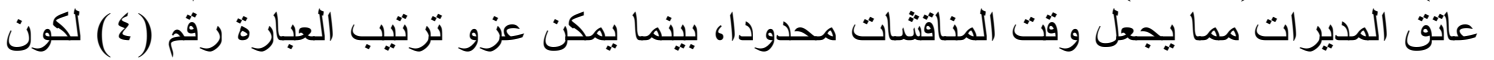

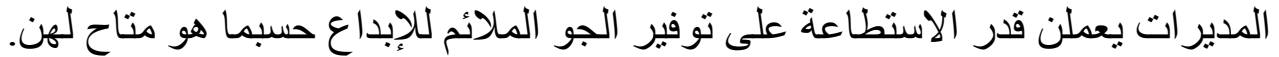

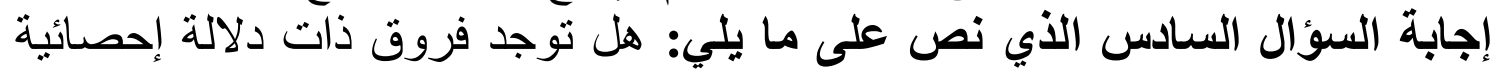

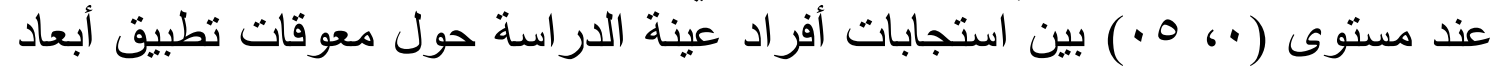

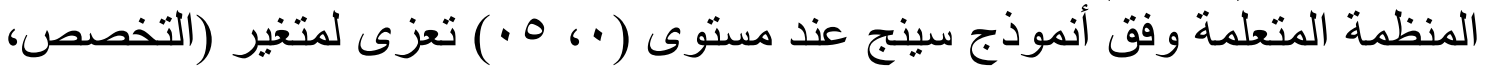

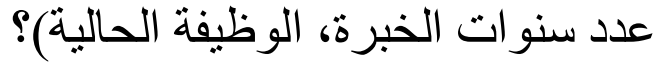

جدول ( • 1) نتيجة اختبار (ت ) لعينتين مستقلتين لتحديد الفروق بين استجابات أفراد عينة

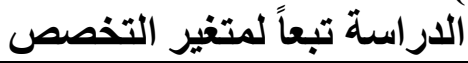

\begin{tabular}{|c|c|c|c|c|c|}
\hline مستوى الدلالة & قيمة (ت) & الكستوسطي & العدد & التخصص & الأبعاد \\
\hline Ir. & \multirow{2}{*}{0 Vo, 1} & 1965 & Tr & علمي & \multirow{2}{*}{ لتمكن الثخصي } \\
\hline غير دالة & & $\cdot V_{G}$ & $\varepsilon V$ & أدبي & \\
\hline . $\varepsilon$ ، & \multirow{2}{*}{. T. } & $I V G Y$ & rT & علمي & \multirow{2}{*}{ النماذج الذهنية } \\
\hline دالة & & 91.1 & $\varepsilon V$ & أدبي & \\
\hline . $\varepsilon_{6}$ & \multirow{2}{*}{$.9 V 6 r$} & $1 \wedge, Y$ & Tr & علمي & \multirow{2}{*}{ الرؤية المشتركة } \\
\hline دالة & & 9161 & $\varepsilon V$ & أدبي & \\
\hline
\end{tabular}




\begin{tabular}{|c|c|c|c|c|c|}
\hline$r \leq 6$ & \multirow{2}{*}{19461} & $.06 \mathrm{Y}$ & $r T$ & علمي & \multirow{2}{*}{ تعلم الفريق } \\
\hline غير دالة & & 1961 & $\varepsilon V$ & أدبي & \\
\hline or 6. & \multirow{2}{*}{. } & $1 T_{6}$ & $r \mu$ & علمي & \multirow{2}{*}{ التفكير النظمي } \\
\hline غير دالة & & .765 & $\varepsilon V$ & أدبي & \\
\hline .76 & \multirow{2}{*}{9.9 .1} & 10.6 & $r T$ & علمي & \multirow{2}{*}{ جميع الأبعاد } \\
\hline غير دالة & & 9161 & $\sum V$ & أدبي & \\
\hline
\end{tabular}

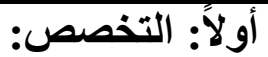

أفادت استجابات أفراد العينة كما هو مبين في جدول ( • () بعدم وجود فروق ذات دلالة التهات

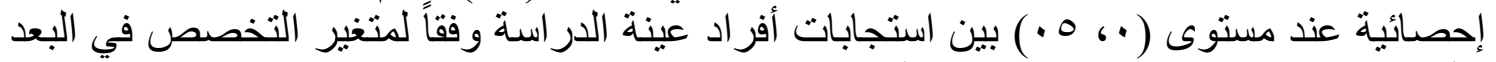

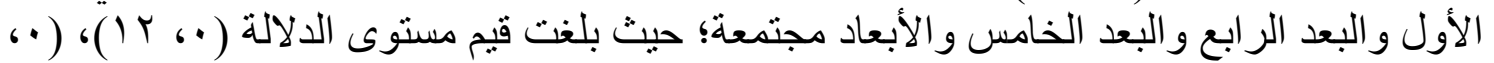

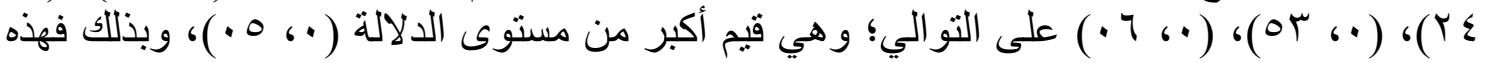

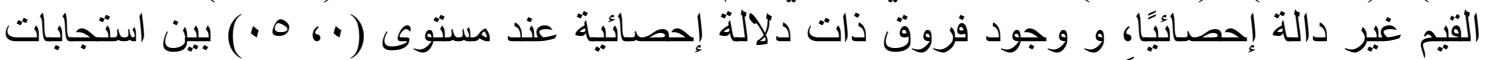

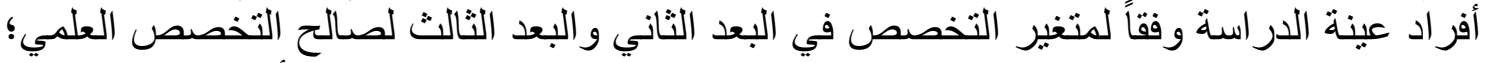

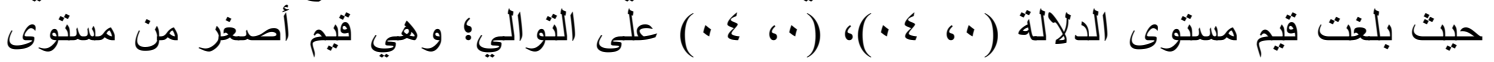

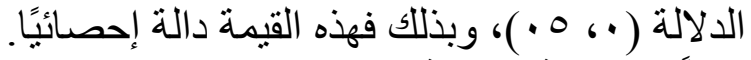

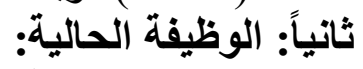

جدول (1 1) نتيجة اختبار (ت ) لعينتين مستقلتين لتحديد الفروق بين استجابات أفراد عينة

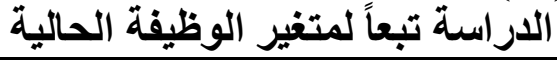

\begin{tabular}{|c|c|c|c|c|c|}
\hline الدلالة & قيمة (ت) & الحسابي & العدد & العمل الحالي & الأبعاد \\
\hline 946 & \multirow{2}{*}{.176} & $1 \cdot 6 r$ & Tr & مديرة & \multirow{2}{*}{ التمكن الشخصي } \\
\hline غير دالة & & $116 r$ & rᄉ & وكيلة & \\
\hline or 6. & \multirow{2}{*}{ ToY .. } & $\cdot V_{6} T$ & Tr & مديرة & \multirow{2}{*}{ النماذج الذهنية } \\
\hline غير دالة & & .164 & rᄉ & وكيلة & \\
\hline 916 & \multirow{2}{*}{$11 \% 6$} & .164 & Tr & مديرة & \multirow{2}{*}{ الرؤية المشتركة } \\
\hline غير دالة & & 9961 & rᄉ & وكيلة & \\
\hline ऍへ 6. & \multirow{2}{*}{$110_{6}}$. & .164 & r & مديرة & \multirow{2}{*}{ تعلم الفريق } \\
\hline غير دالة & & 1961 & rᄉ & وكيلة & \\
\hline$\Lambda V_{6}$. & \multirow{2}{*}{1796} & .967 & Tr & مديرة & \multirow{2}{*}{ التفكير النظمي } \\
\hline غير دالة & & .1 .4 & rᄉ & وكيلة & \\
\hline $7 \leq 6$ & \multirow{2}{*}{$\sum V \cdot 6$} & .7 .4 & r & مديرة & \multirow{2}{*}{ جميع الأبعاد } \\
\hline غير دالة & &.$Y_{6}$ & rᄉ & وكيلة & \\
\hline
\end{tabular}

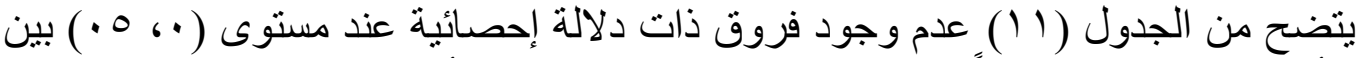

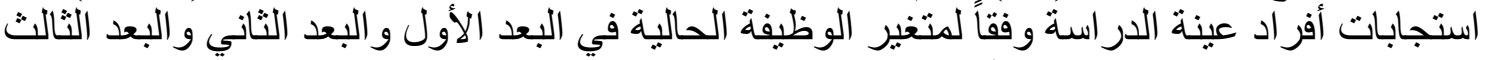

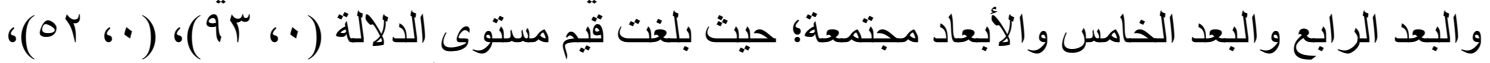

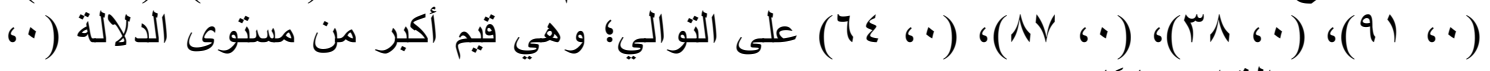
0 () )، و غير دالة إحصائبًا. 


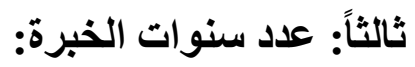
جدول (r I): نتيجة اختبار تحليل التباين الأحادي (ANOVA) لتحديد دلالة الفروق بين

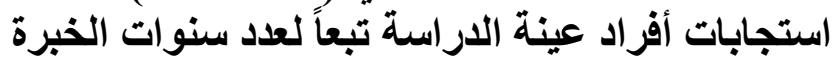

\begin{tabular}{|c|c|c|c|c|c|c|}
\hline مستوى الدلالة & فيمة ( & متوسط المربعات & درجة لحرية & لمربعات & مصدر التباين & الأبعاد \\
\hline \multirow{3}{*}{ غير دالة } & \multirow{3}{*}{ Y } & $1 \wedge \leq 6$ & r & r.4 . & المجمو عات & \multirow{3}{*}{ الثخصي التمكن } \\
\hline & & .916 & TV & $.7 V 67$ & المجمو عات & \\
\hline & & & 79 & \&TO ، T & المجموع & \\
\hline \multirow{3}{*}{ 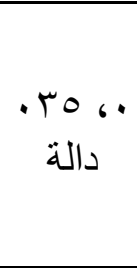 } & \multirow{3}{*}{ r، سזם } & $\sum \wedge T_{6}$ & r & $9 \vee Y_{6}$. & المجمو عات & \multirow{3}{*}{ الذهاذج } \\
\hline & & $1 \pi \wedge 6$ & TV & Y) $\leq 69$ & المجمو عات & \\
\hline & & & 79 & $1 \wedge 761$. & المجموع & \\
\hline \multirow{3}{*}{ غير دالة ، ؛ } & \multirow{3}{*}{ Vos . } & $r_{1} r_{6}$ & r & $\leq r \leq 6$. & المجمو عات & \multirow{3}{*}{ المشتركة الروية } \\
\hline & & rAl 6 & $7 V$ & AY7 6 & المجمو عات & \\
\hline & & & 79 & 10.619 & المجموع & \\
\hline \multirow{3}{*}{ غير دالة } & \multirow{3}{*}{ VON .. } & $r 1 \cdot \ldots$ & r & ₹196. & المجمو عات & \multirow{3}{*}{ تعلم الفريق } \\
\hline & & TVV6. & TV & Or & المجمو عات & \\
\hline & & & 79 & 904.11 & المجموع & \\
\hline \multirow{3}{*}{ غير دالة } & \multirow{3}{*}{ sor , 1} & $1 \wedge 16$ & r & r. & المجمو عات & \multirow{3}{*}{ النظمي } \\
\hline & & $1 \times 96$. & $7 V$ & 777 เ & المجمو عات & \\
\hline & & & 79 & $\cdot \leqslant Y \quad 69$ & المجموع & \\
\hline \multirow{3}{*}{ غير دالة ل، } & \multirow{3}{*}{110,1} & $r .96$. & r & $\leqslant 1 \wedge 6$ & المجمو عات & \multirow{3}{*}{ جميع الأبعاد } \\
\hline & & 1106 & TV & $V) \leq 6$ & المجمو عات & \\
\hline & & & 79 & A I I I & المجموع & \\
\hline
\end{tabular}

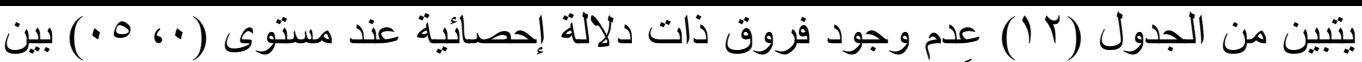

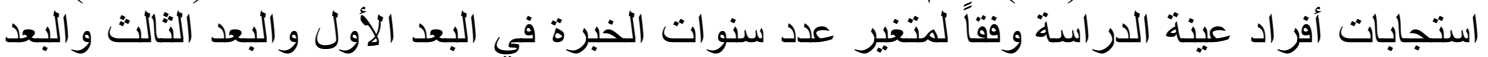

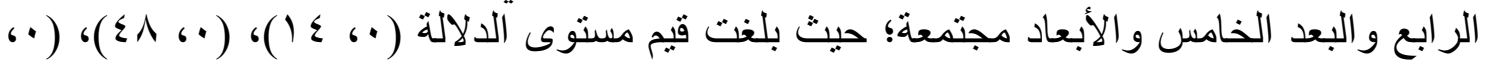

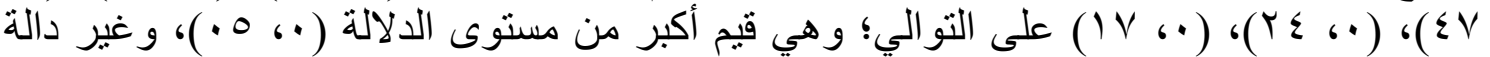

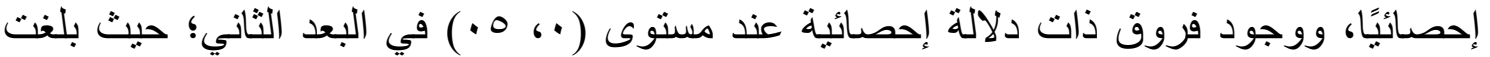

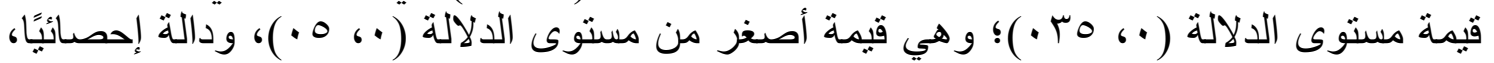


ولتحديد اتجاه الفروق في البعد الثاني، تم استخدام الاختبار البعدي (LSD)، ويوضح الجدول التالي

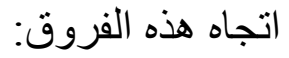

\begin{tabular}{|c|c|c|c|c|}
\hline البعد & سنوات الخبرة (I) & $\begin{array}{c}\text { سنوات الخبرة } \\
\text { (J) }\end{array}$ & المتوقين & الدلالةى \\
\hline البعد الثاني & من خمس سنوات إلى أقل من & عشر سنوات & $r \cdot$. & . \\
\hline
\end{tabular}

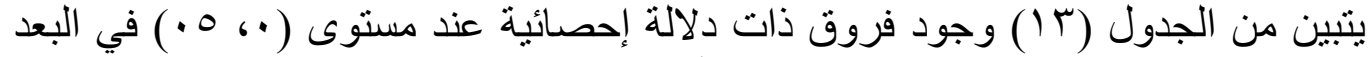

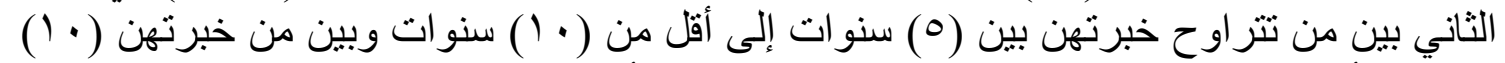

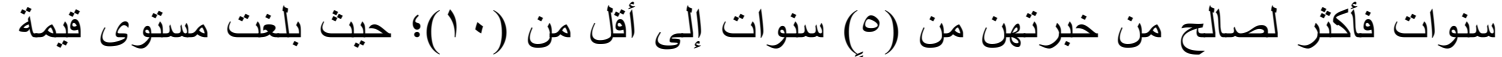

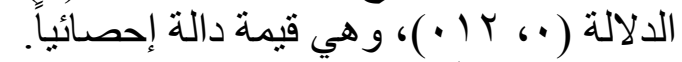

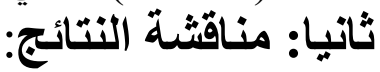

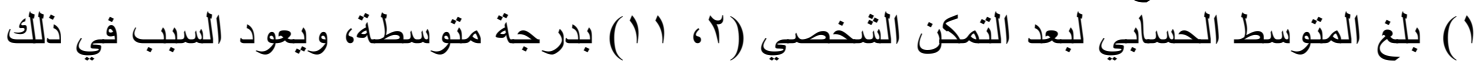

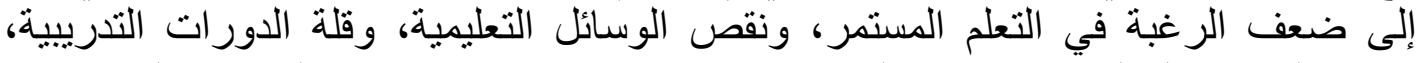

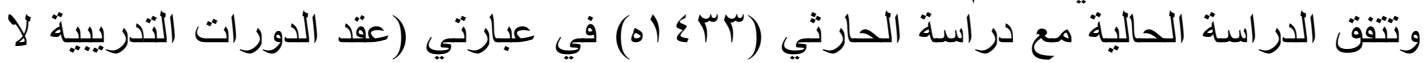

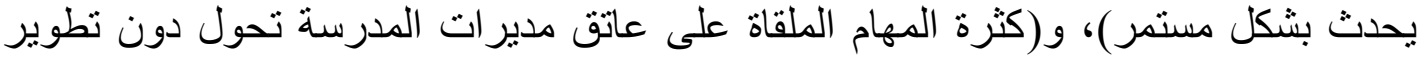

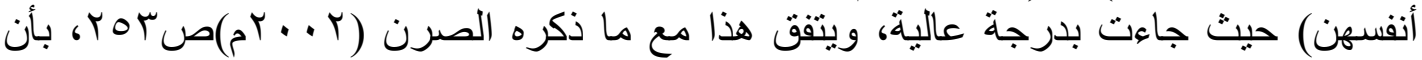

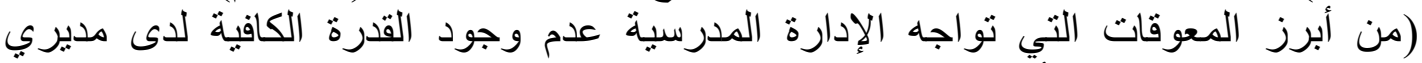

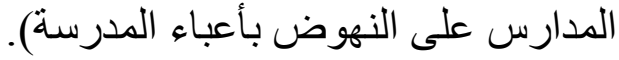

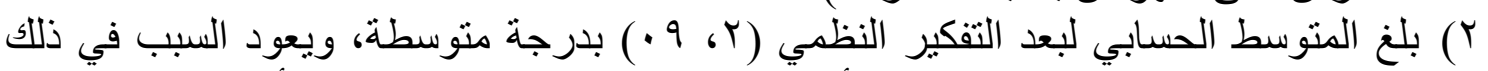

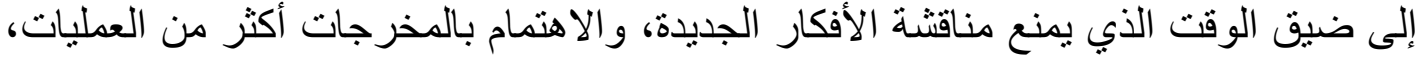

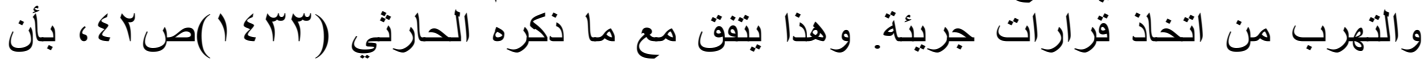

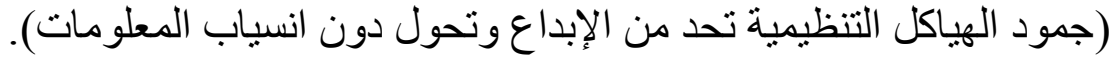

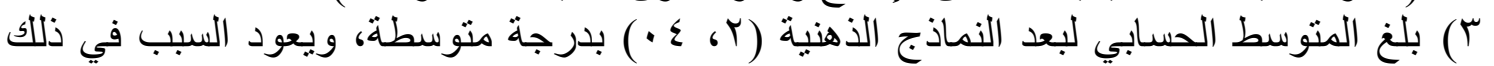

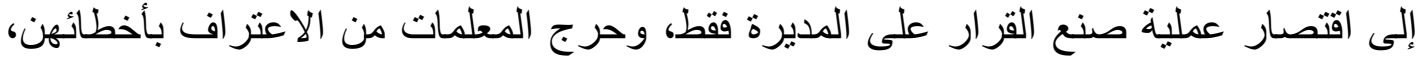

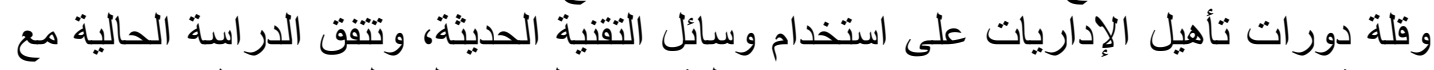

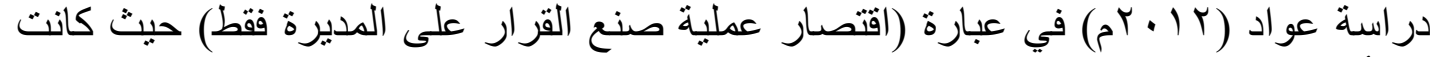

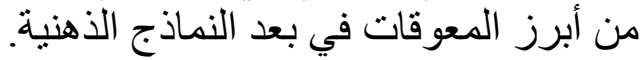

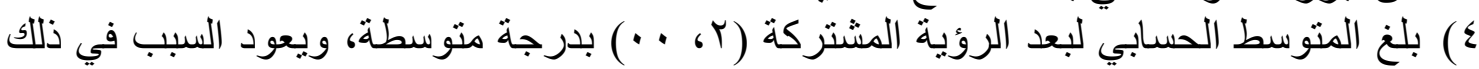

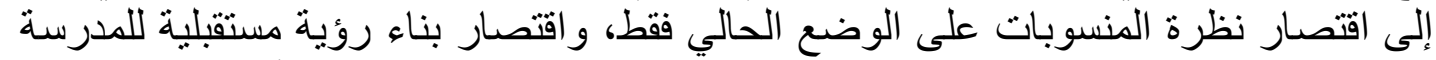

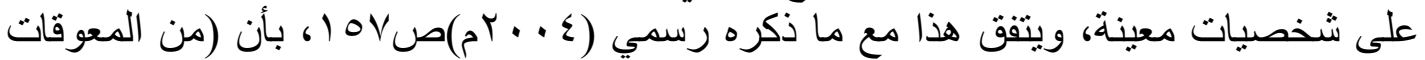

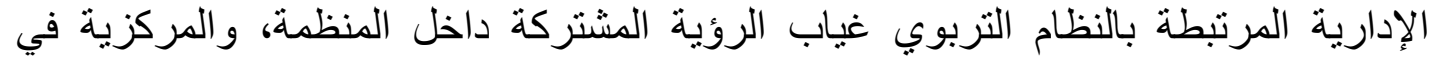

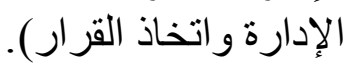

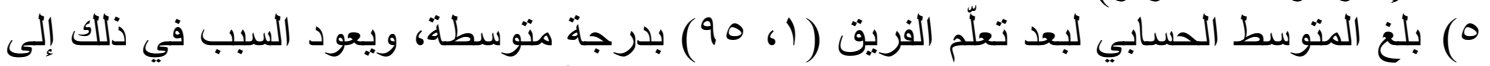

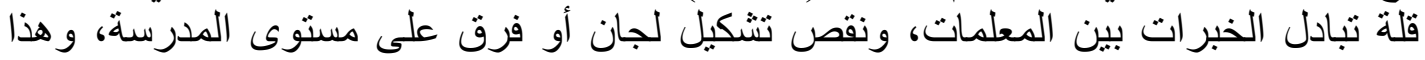

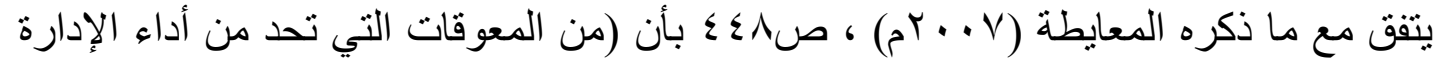

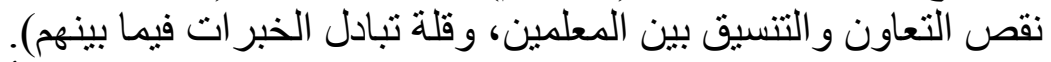

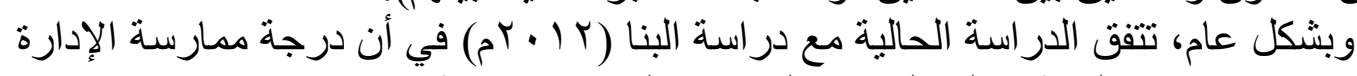

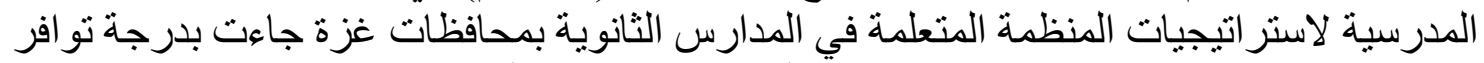

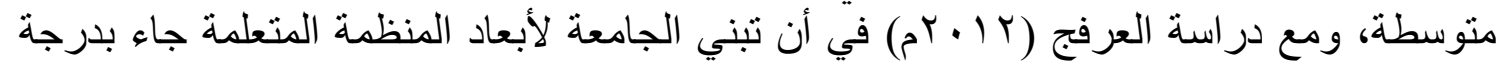


متوسطة، ومع دراسة عاشور (^ . . rم) في أن تصور ات المدر اء و المعلمين في المدارس الثانوية

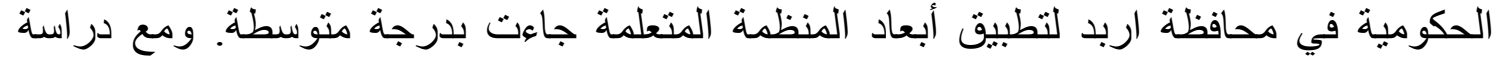

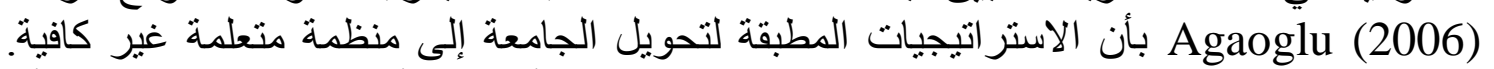

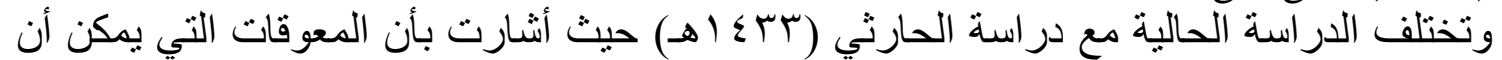

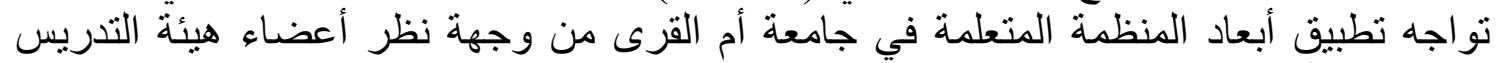
و القيادات الأكاديمية فيها جاءت بدرجة الماد عالية.

7) أظهرت الدر اسة الحالية وجود فروق ذات دلالة إحصائية عند مستوى ( •، 0 ـ ) بين استجابات

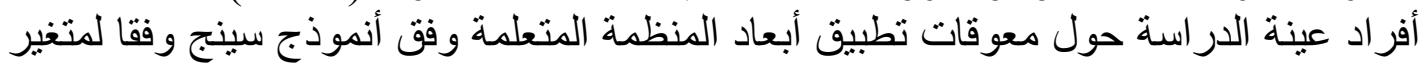

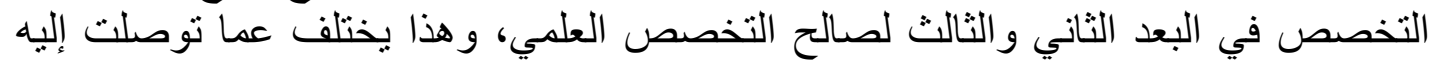

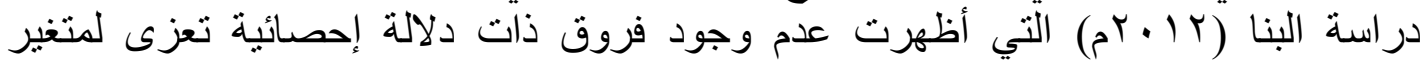

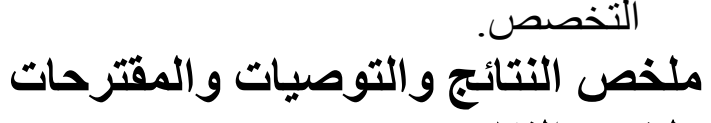

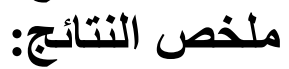

ا ـ أظهرت النتائج أن المعوقات التي تواجه الإدارة المدرسية عند تطبيق أبعاد المنظمة المتعلمة

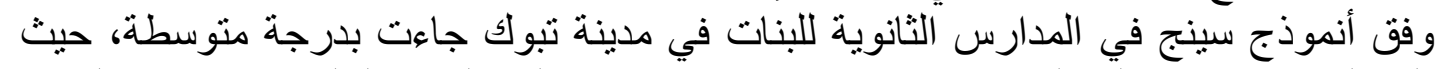

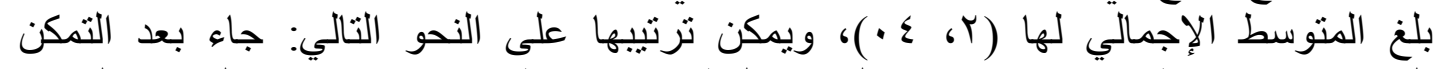

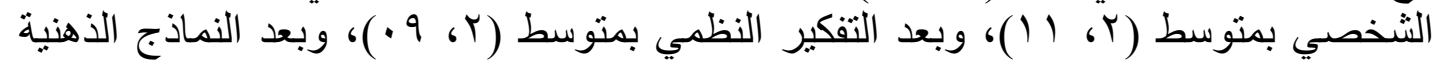

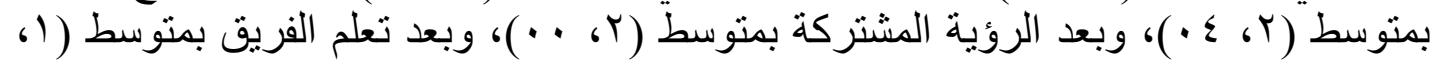
. (90

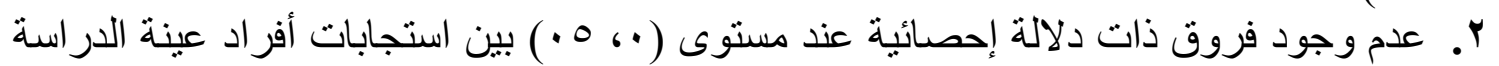

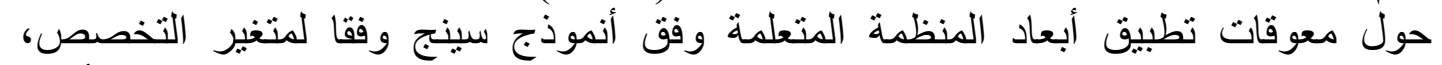

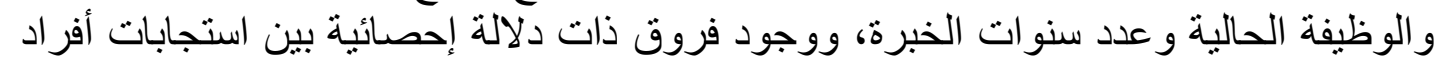

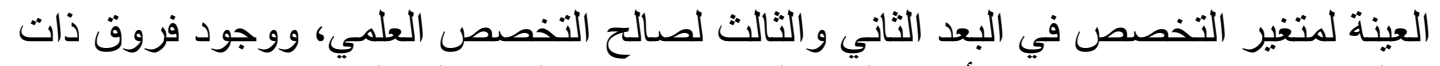

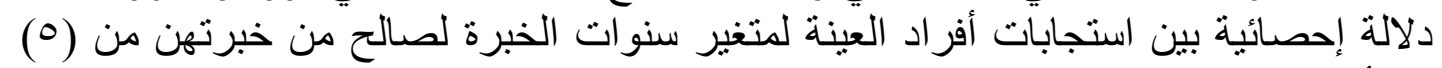

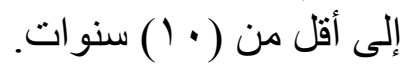
التوصيات: في ضوء النتائج توصي الدر اسة بجملة من التوصيات أهمها:

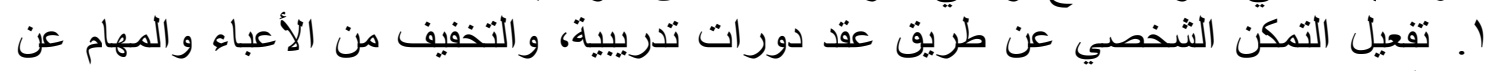
المنسوبات. r. تطبيق النماذج الذهنية في الإدارة المدرسية عن طريق إثراك المنسوبات في عملية صنع

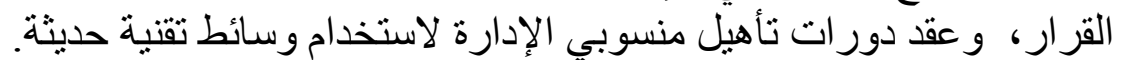

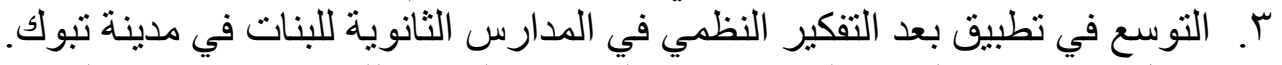

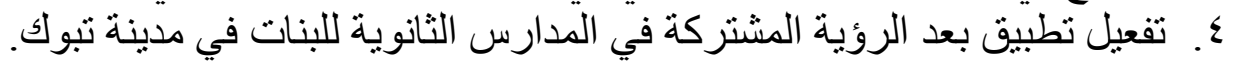

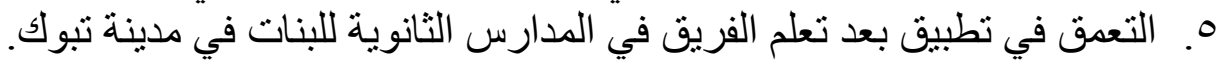

المقتر حاث: فئ في

لما كان ميدان البحث يفتقر إلى الدراسات التي تناولت موضو عات مماثلة لهذا البحث تقتر ح الدراسة:

ا إجراء دراسات جديدة للتعرف على المتطلبات التي ينبغي أن تتوافر لتطبيق أبعاد المنظمة المتعلمة.

r. إجر اء دراسات حول علاقة تطبيق أبعاد المنظمة المتعلمة في المدارس الثانوية للبنات بالميزة التنافسية. r. زيادة الأمو ال المخصصة للإنفاق على الدور ات التدريبية. 


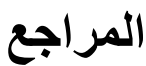

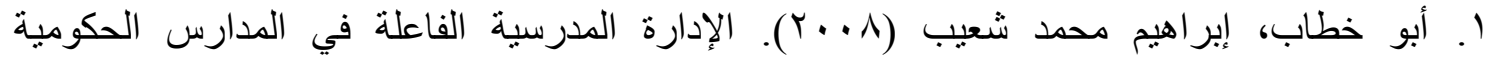

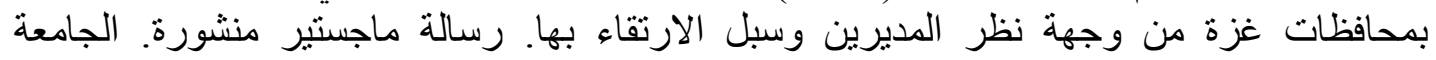

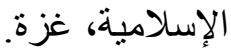

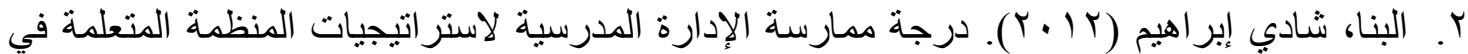

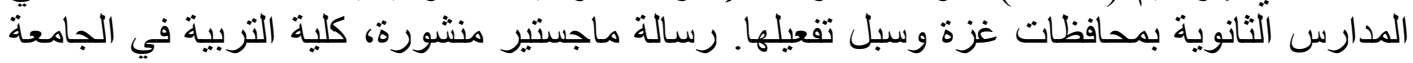

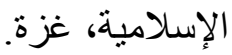

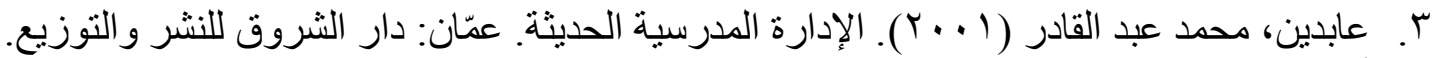

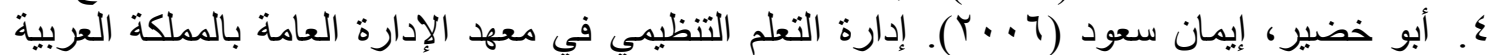

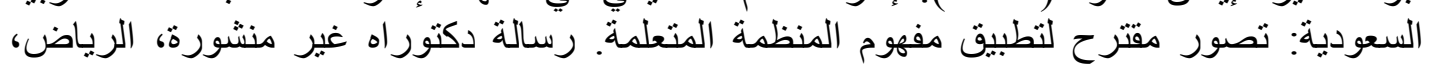
جامعة الملك سعود.

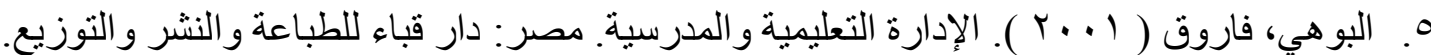

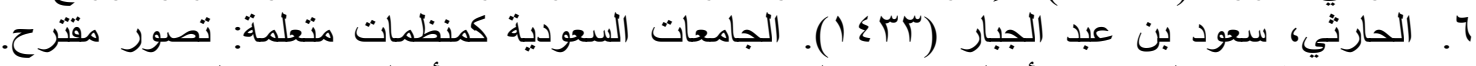

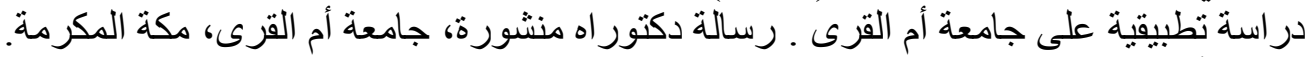

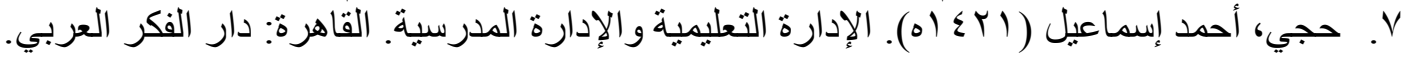

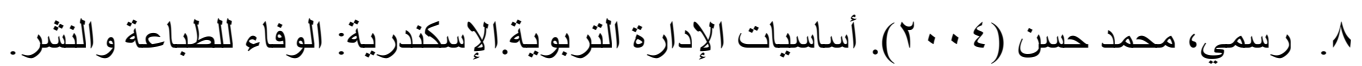

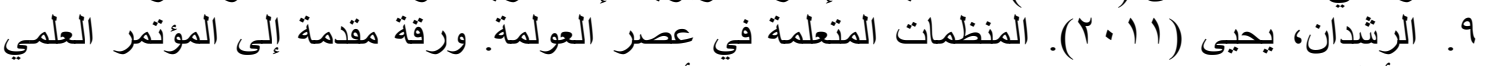

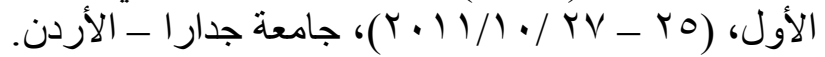

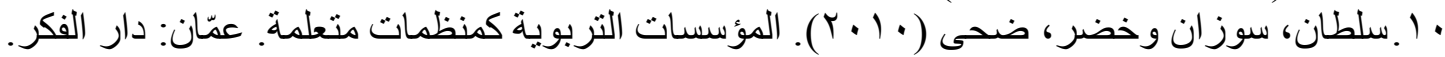

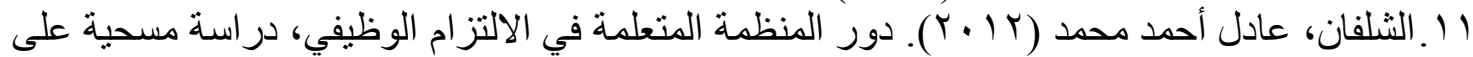

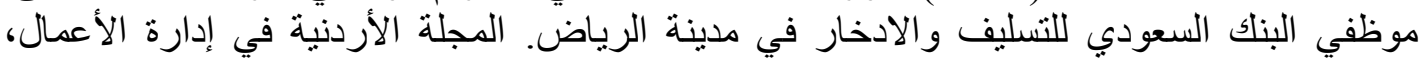

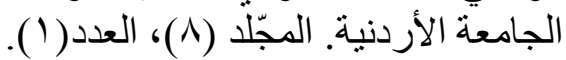

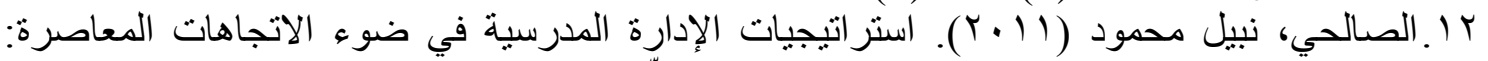

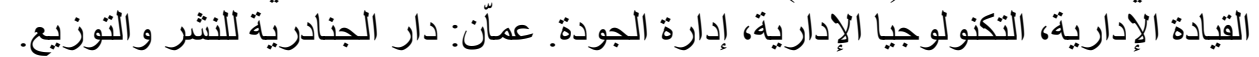

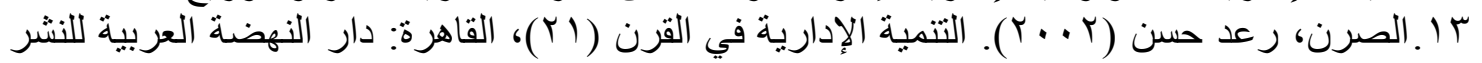
و التوزيع.

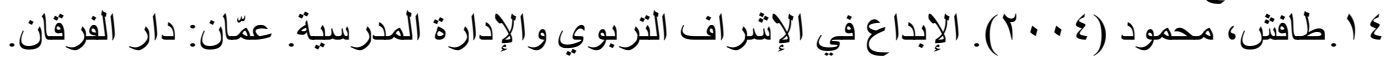

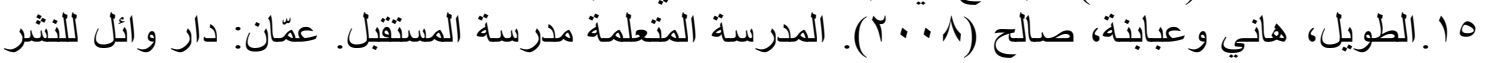
و التوزيع.

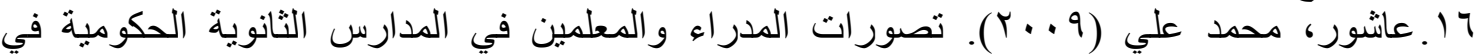

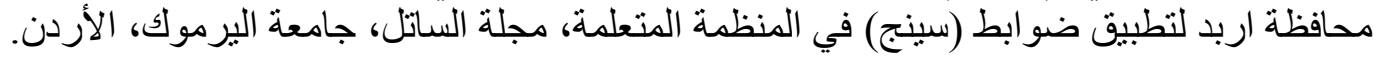

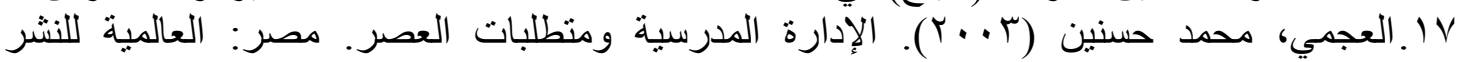
و التوزيع.

1 ا. العرفج، عبد المحسن (Y (Y Y). واقع تبني جامعة الملك فيصل لأبعاد المنظمة المتعلمة. المجلة

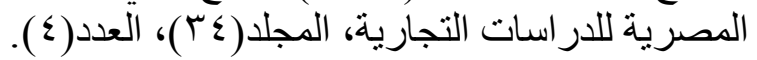

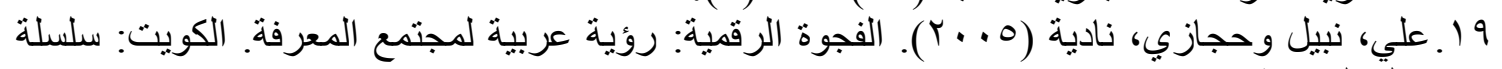
عالم المعرفة.

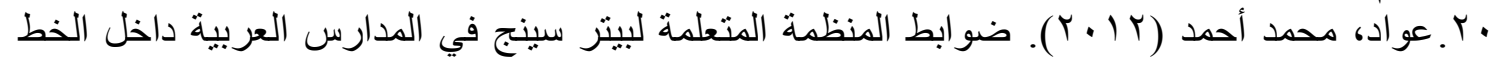

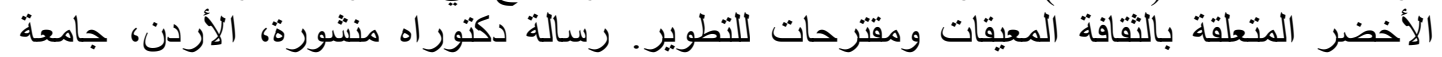
اليرموك.

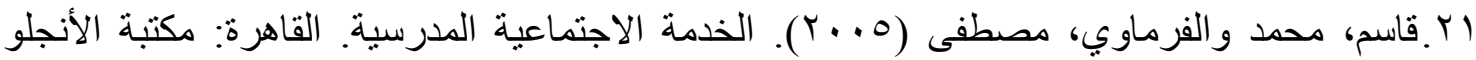
المصريّة.

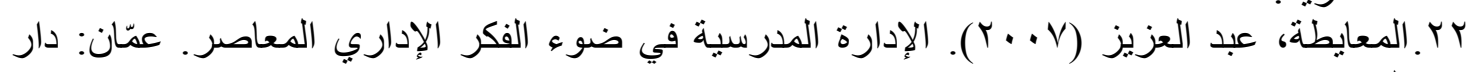




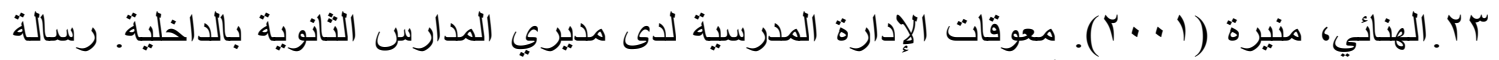

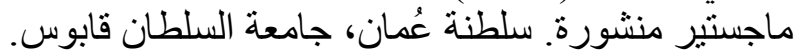

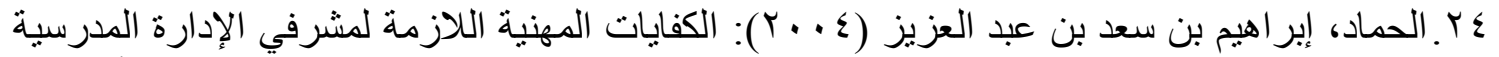

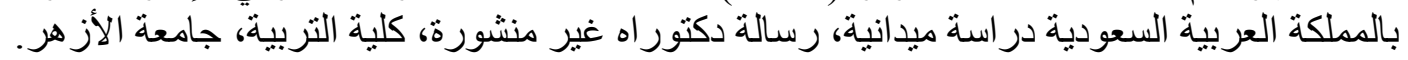

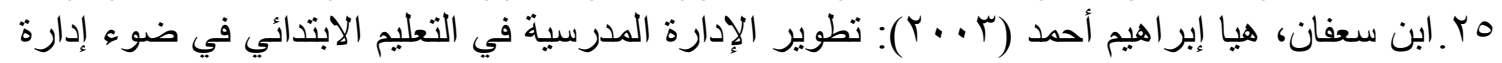

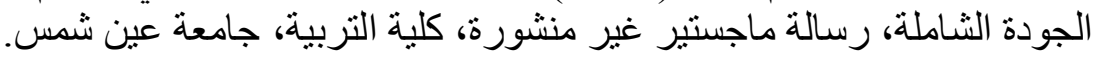

26. Agaoglu ‘ E. (2006). The Reflection of the Learning Organization Concept to School of Education، Turkish Online Journal of Distance Education-TOJDE، Vol. (7)، No. (1)‘ p132-148.

27. Martinette، C. (2002) . Learning Organization and Leadership Style . Lynchburg Fire \& EMS Department، Lynchburg. Virginia .

28. Park · J. (2008) Validation of Senge's Learning Organization Model With Teachers OF Vocational high Schools at the Seoul Megalopolis، Asian Pacific education review، Vol.(9)، No.(3)‘ p270 -284

29. 28 .Senge، P. (2004): The fifth Discipline: the Art and Practice of the Learning Organization`New York، Doubleday.

30. Sparks ، D. (2002). Why change Is So Challenging For Schools. An Interview With Peter Senge (an electronic version). Journal Of Stuff Development، Vol.(22)، No.(3)، U.S.A.

31. Thomas، K. \& Allen، S. (2006)، The learning organization: a metanalysis of themes in literature، The Learning Organization، Vol. (13) ‘No.(2)‘ pp.123139. 


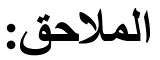

(اختياري)

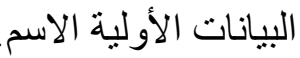

يرجى تظليل الخيار المناسب مما يلي:

O

المؤهل : بكالوريوسو ماجستير أو دكتور اه

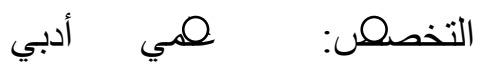

العمل الحافي: مهمة وكيلة

سنوات العمل في الوظيفة الحالية:

أقل من خمس سنطت من خمس سنوات إلى أقل من عشر سنو اتممن عشر سنوات فأكثر م

\begin{tabular}{|c|c|c|c|c|}
\hline \multicolumn{3}{|c|}{ درجة التو افر } & \multirow[t]{2}{*}{ المعــــوقات } & \multirow{2}{*}{ 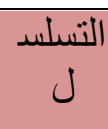 } \\
\hline ضعيفة & متوسطة & عالية & & \\
\hline \multicolumn{5}{|c|}{ أولا: التمكن الشخصي } \\
\hline & & & ضعف الرغبة في التعلم المستمر & -1 \\
\hline & & & نقص الوسائل التعليمية الحديثة & $-{ }^{-1}$ \\
\hline & & & عقد الدورات التدريبية لا يحدث بشكل مستمر & -4 \\
\hline & & & قيباعة إدارة المدرسة بأن تبني المفاهيم الحديثة في الإدارة & $-\varepsilon$ \\
\hline & & & تطوة ألفهام الملقاة على عاتق مدير ات المدرسة تحول دون & -0 \\
\hline & & & الإدارة المدرسية البر امج المقدة في مركز التدريب التربوي لتطوير & -7 \\
\hline & & & غموض أهداف العمل للغالبية & $-V$ \\
\hline & & & للمدرسة القدرة النتائج التي تلى المقارنة بين الأهداف المرسومة & -1 \\
\hline \multicolumn{5}{|c|}{ ثانيا: النماذج الذهنية } \\
\hline & & & حرص الإدارة على التطبيق الحرفي للوائح والقو انين & -9 \\
\hline & & & اعتر اف المعلمات بأخطائهن يسبب لهن الحرج & -1 \\
\hline & & & اقتصسار عملية صنع القرار على المديرة فقط & -11 \\
\hline & & & تدخل المعلمات في حل المشكلات يزيد من تفاقم المشكلة & -14 \\
\hline & & & حرية الر أي بين الإدارة والمعلمات أمر غير و اقعي & -14 \\
\hline & & & نقص العلم بالخبرات الإدارية المتميزة & $-1 \leqslant$ \\
\hline & & & الاعتقاد السائد بأن التغيير سيؤدي إلى مخاطرة غير & -10 \\
\hline & & & قلة دورات تأهيل منسوبي الإدارة على استخدام وسائط & -17 \\
\hline
\end{tabular}




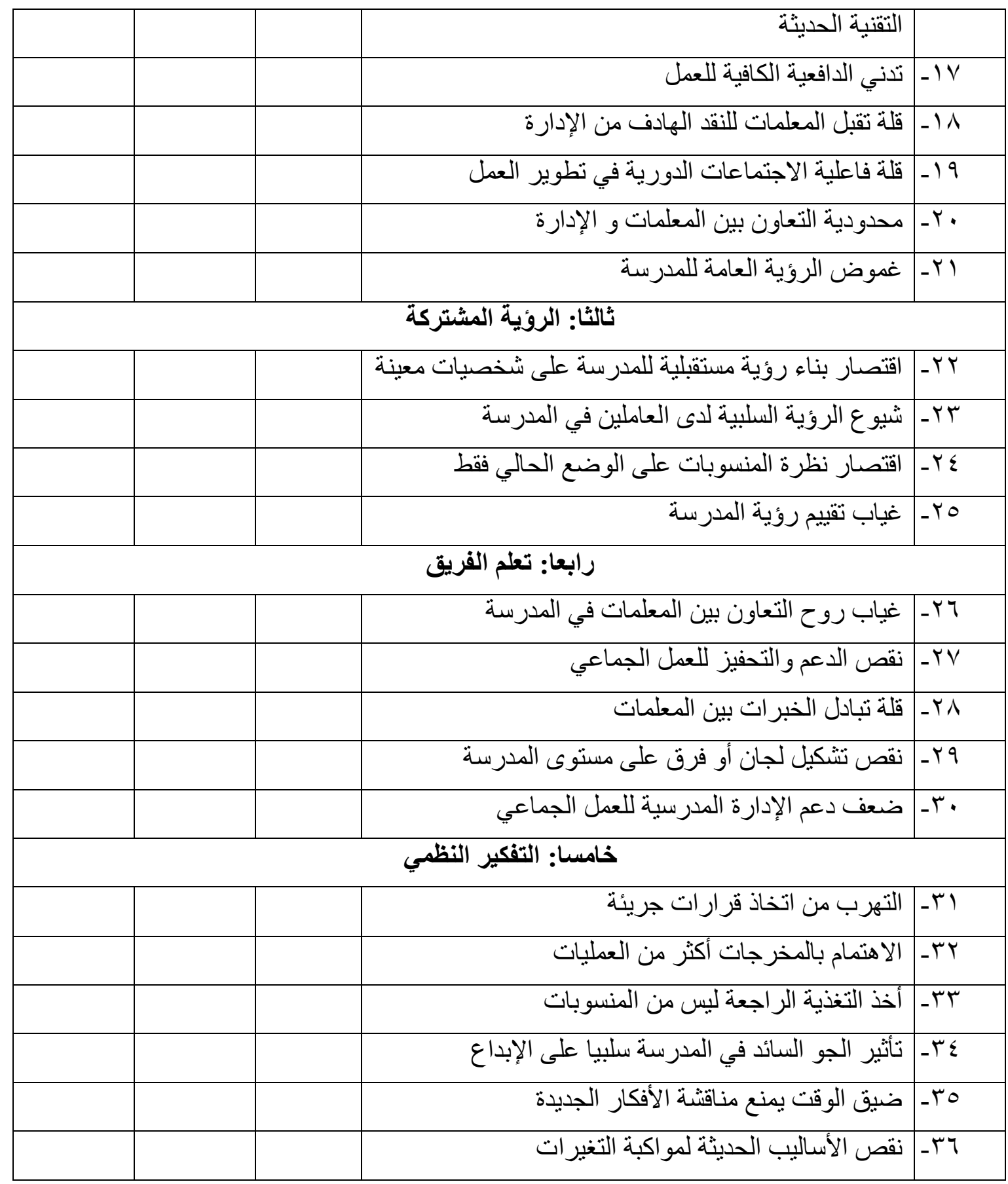

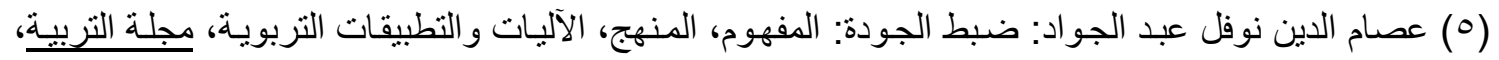

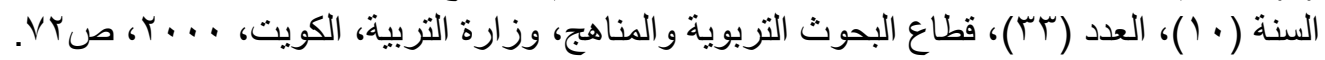

